\title{
Experimental study on water evaporation from sand using environmental chamber
}

\author{
Wei-Kang Song, Yu-Jun Cui, Anh Minh Tang, Wen-Qi Ding, and Thanh Danh Tran
}

\begin{abstract}
Large-scale evaporation experiments were conducted on bare sand using an environmental chamber. Four different atmospheric conditions and various drying durations were imposed on the soil sample. Atmospheric parameters (air flow rate, relative humidity, and temperature) and response of the soil (volumetric water content, temperature, and soil suction) were both monitored simultaneously. Notably, the temperature and matric suction at the soil surface were monitored using an infrared thermometer and high-capacity tensiometer, respectively. The results show that the air and soil temperatures depend on the evaporation process and atmospheric conditions. In addition, volumetric water content in the near-surface zone is strongly affected by the evaporation process and changes linearly over depth. The evaporation rate is strongly dependent on the air conditions.
\end{abstract}

Key words: soil water evaporation, environmental chamber, Fontainebleau sand, soil surface suction.

Résumé : Des expériences d'évaporation à grande échelle ont été réalisées sur du sable nu à l'aide d'une chambre environnementale. Quatre conditions atmosphériques différentes et des durées de séchage variées ont été imposées à l'échantillon de sol. Les paramètres atmosphériques (débit d'air, humidité relative et température) et les réponses du sol (teneur en eau volumique, température et succion du sol) ont été mesurés simultanément. Par exemple, la température et la succion matricielle à la surface du sol ont été mesurées respectivement à l'aide d'un thermomètre à infrarouge et d'un tensiomètre à haute capacité. Les résultats démontrent que les températures de l'air et du sol dépendent du processus d'évaporation et des conditions atmosphériques. De plus, la teneur en eau volumique dans la zone près de la surface est fortement affectée par le processus d'évaporation et varie linéairement en fonction de la profondeur. Le taux d'évaporation est très dépendant des conditions de l'air. [Traduit par la Rédaction]

Mots-clés : évaporation de l'eau du sol, chambre environnementale, sable de Fontainebleau, succion à la surface du sol.

\section{Introduction}

Soil water evaporation at the air-soil interface is an important water cycle and energy exchange process, which causes many problems in various fields: soil degradation in arid areas with a high evaporation rate (Xue and Akae 2012), soil salinization in arid and semi-arid regions (e.g., Shimojimaa et al. 1996; Zarei et al. 2009; Xue and Akae 2012), damage of buildings and geotechnical constructions due to water loss (Cui and Zornberg 2008; Corti et al. 2009, 2011), etc. This shows the importance of investigating the mechanisms of soil water evaporation. On the other hand, the study of this process has significant practical benefits in various fields: estimating the amount of water loss in the assessment of soil management technologies in agriculture (Qiu et al. 1998), predicting evaporation flux in design of soil cover of mine tailings (Wilson 1990; Wilson et al. 1994, 1997; Yanful and Choo 1997), investigating the long-term performance of moisture-retaining soil covers (Yang and Yanful 2002; Yanful et al. 2003), designing evapotranspirative cover systems for waste containment and mining sites (Cui and Zornberg 2008), classifying landfill sites according to climatic water balance (Blight 2009), etc. Moreover, the investigation of soil water evaporation is also an important issue in geotechnical engineering (Cui et al. 2010, 2013).

For bare soils, the water evaporation process is controlled by both atmospheric conditions and soil conditions (Wilson 1990;
Wilson et al. 1994; van de Griend and Owe 1994; Qiu et al. 1998). Regarding the atmospheric conditions, it appears that evaporation rate is sensitive to wind speed at the beginning of the process when the soil surface is wet (Kondo et al. 1992; Yamanaka et al. 1997), whereas increasing wind speed results in a reduction of evaporation rate when the soil surface is dry (Yamanaka et al. 1997). An increase in relative humidity decreases the evaporation rate and vice versa (Yamanaka et al. 1997) - evaporation ceases when the vapor pressure at the soil surface becomes equal to that of air (Yanful and Choo 1997). The evaporation rate determined from the field meteorological data was found higher at lower relative humidity, higher wind speed, higher air temperature, and stronger solar radiation (Cui et al. 2005; Cui and Zornberg 2008). Furthermore, the field daily evaporation rate was also found to be dependent on the atmospheric conditions: a high net radiation results in high latent heat flux and hence high evaporation rate; thereby, most evaporation takes place during daytime (Blight 1997; Aluwihare and Watanabe 2003). As far as soil conditions are concerned, the evaporation rate is dependent on the soil texture (Wilson 1990; Wythers et al. 1999), initial water content (Wang 2006), hydraulic conductivity (Wilson et al. 1994) and water retention capacity (Yanful and Choo 1997). In addition, the drainage condition and water table level also significantly affect the process of evaporation (Yang and Yanful 2002).

Received 19 April 2013. Accepted 7 November 2013.

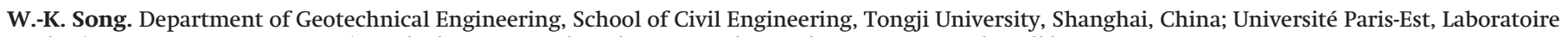
Navier (UMR CNRS-IFSTTAR-ENPC), Ecole des Ponts ParisTech, 6-8, av. Bl. Pascal, F-77455 Marne-la-Vallée, France.

Y.-J. Cui and A.M. Tang. Université Paris-Est, Laboratoire Navier (UMR CNRS-IFSTTAR-ENPC), Ecole des Ponts ParisTech, 6-8, av. B1. Pascal, F-77455 Marne-la-Vallée, France.

W.-Q. Ding. Department of Geotechnical Engineering, School of Civil Engineering, Tongji University, Shanghai, China.

T.D. Tran. Centre de Géosciences-Fontainebleau, Mines ParisTech, Fontainebleau, France.

Corresponding author: Yu-Jun Cui (e-mail: cui@cermes.enpc.fr). 
Basically, soil surface temperature and suction are two essential parameters controlling soil water evaporation. However, these two parameters have scarcely been investigated experimentally, in particular the soil surface suction.

In the present work, a large-scale compacted Fontainebleau sand sample (1000 $\mathrm{mm}$ in length, $800 \mathrm{~mm}$ in width, and $300 \mathrm{~mm}$ in height) was subjected to four evaporation tests in an environmental chamber under various controlled atmospheric conditions (i.e., different values of air relative humidity, temperature, and air-flow rate) and with a steady water table. Air conditions and the response of soil parameters were monitored during the tests, including soil surface temperature and matric suction using an infrared thermometer and high-capacity tensiometer, respectively. The recorded data allow better understanding of the soil water evaporation mechanisms on one hand and further theoretical and numerical analyses on the other.

\section{Materials}

The soil studied is the Fontainebleau sand, with a specific gravity of 2.64. The values of its minimum and maximum unit masses are 1.39 and $1.75 \mathrm{Mg} / \mathrm{m}^{3}$, respectively. The effective grain size, $D_{10}$, is $0.14 \mathrm{~mm}$ and the coefficient of uniformity, $C_{\mathrm{u}}=D_{60} / D_{10}$ (where $D_{60}$ and $D_{10}$ are the particle sizes for which $60 \%$ and $10 \%$ of the sample are finer than $D_{60}$ and $D_{10}$, respectively), is 1.6 (Delfosse-Ribay et al. 2004). The grain size distribution curve determined by sieve analysis is shown in Fig. 1.

\section{Testing apparatus}

The evaporation tests were carried out in a large-scale environmental chamber setup (see Fig. 2). This setup includes an environmental chamber (i.e., an transparent acrylic tank with $800 \mathrm{~mm}$ internal width, $1000 \mathrm{~mm}$ internal length, and $895 \mathrm{~mm}$ height), a wind supply unit, an air collection unit, a water supply unit, and a data-logging system. Upon initiation of the evaporation test, the wind supply unit supplies an air stream with a controlled air-flow rate, temperature, and relative humidity to the chamber. The air collection unit collects the moist air passing through the chamber and records its temperature and relative humidity. The water supply unit can control the water level during evaporation. The datalogging system records all the results from different sensors. It is noted that the evaporation rate can be determined by changes in absolute humidity and air flow rate. Furthermore, various sensors with different applications were installed at different locations of the soil sample and the chamber. More specifically,

- five soil moisture sensors (ThetaProbe (ML2x)) for recording changes in soil volumetric water content were buried at different depths of the soil sample;

- six resistance temperature detectors (PT1000) for measuring soil temperature were also buried inside the soil sample over its depth;

- five thermistors monitoring air temperature were fixed at different heights above the soil surface;

- six humidity sensors (T3111 transmitter) were also placed at different locations of the chamber for monitoring of air relative humidity and temperature;

- an infrared thermometer (Pyropen-D) was used to measure the soil surface temperature;

- five high-capacity tensiometers were installed at different depths for the sake of matric suction measurement;

- a flowmeter (MAS-3120) and anemometer (Testo 435-2) were used to measure air flow rate and wind speed, respectively.

The details of the sensors used are presented in Table 1. A sketch of the sensor arrangement is shown in Fig. 3. More details of this environmental chamber and the sensors used can be found in Song et al. (2013).
Fig. 1. Grain size distribution curve of Fontainebleau sand (data from Delfosse-Ribay et al. 2004).

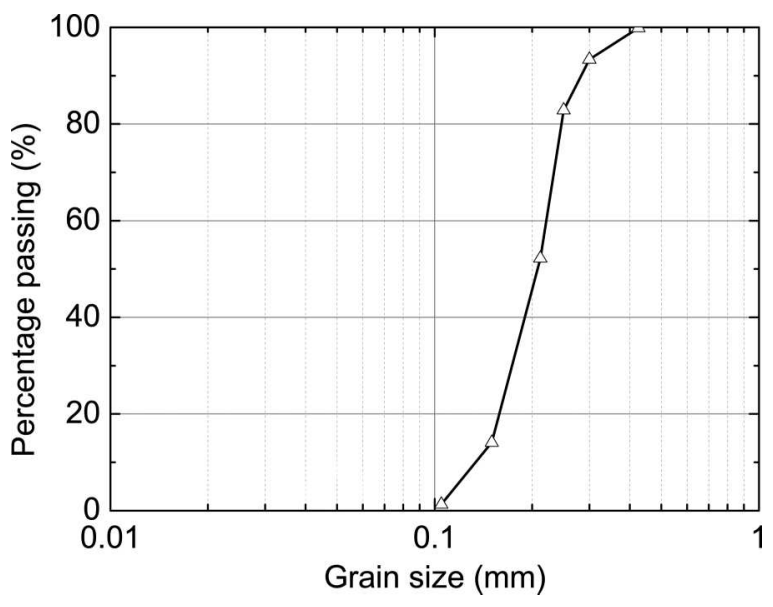

\section{Testing methodology}

The dry Fontainebleau sand was compacted in $50 \mathrm{~mm}$ thick layers in the environmental chamber (Fig. 4a). A soil layer of $300 \mathrm{~mm}$ total thickness was compacted at a dry unit mass of $1.7 \mathrm{Mg} / \mathrm{m}^{3}$. During the compaction, various sensors were installed in the soil: six PT1000 sensors were installed every $50 \mathrm{~mm}$ (i.e., 25, $75,125,175,225$, and $275 \mathrm{~mm}$ depths) and two ThetaProbe sensors were buried at 125 and $225 \mathrm{~mm}$ below the soil surface. The other three ThetaProbe sensors were buried after soil saturation in the first $60 \mathrm{~mm}$ below the soil surface (i.e., 25, 40, and $55 \mathrm{~mm}$ depths) (Fig. $4 b$ ). Five thermistors were fixed at different elevations (i.e., $80,185,275,380$, and $465 \mathrm{~mm}$ heights) along one inside wall of the chamber (Fig. 4c). Three relative humidity sensors (T3111 transmitter) were installed at the soil surface and at various heights (50 and $275 \mathrm{~mm}$ heights), allowing air relative humidity to be monitored (Fig. 4c). An anemometer was fixed at $50 \mathrm{~mm}$ above the soil surface for the measurement of wind speed. Note that the chamber cover was sealed with silicon to ensure air-tightness. For relative humidity at the inlet, outlet, and in the laboratory, three other relative humidity sensors were fixed in a plastic cell at the inlet, in the air collection unit, and outside the chamber. The infrared thermometer was fixed on the cover to monitor the soil surface temperature (Fig. $4 d$ ).

Subsequent to soil compaction and sensor installation, the soil column was saturated through the water tank connected to the bottom of chamber. After saturation, the water level in the tank was lowered to a level close to the bottom of the soil layer and was kept constant during the tests. Meanwhile, four high-capacity tensiometers, constructed in-house, for soil matric suction measurement within a range of 1.5 MPa were installed on two sides of the wall at different depths (i.e., 25, 77, 173, and $276 \mathrm{~mm}$ below the soil surface) and one tensiometer was placed at the soil surface allowing the measurement of near-surface suction. This type of tensiometer is composed of a porous ceramic stone with an air-entry value of $1.5 \mathrm{MPa}$, a specially designed strain gage glued on a diaphragm, and a very thin water reservoir $(0.1 \mathrm{~mm}$ thick) between them (Cui et al. 2008a; Muñoz-Castelblanco et al. 2012). Prior to use, the tensiometer needs to be saturated in a saturation cell with de-aired and distilled water under a pressure as high as $4 \mathrm{MPa}$ (Cui et al. 2008a). Meanwhile, the calibration is completed during this saturation process. More details about this tyoe of tensiometer can be found in Cui et al. (2008a), Tang et al. (2010), and Muñoz-Castelblanco et al. (2012).

The tests were conducted under various controlled air conditions. The compressed air in the laboratory was used and its pressure was controlled using a regulator. The air flow was measured by a flowmeter to an accuracy of $\pm 1.5 \%$ over a working range of 
Fig. 2. Experimental set-up with the environmental chamber.

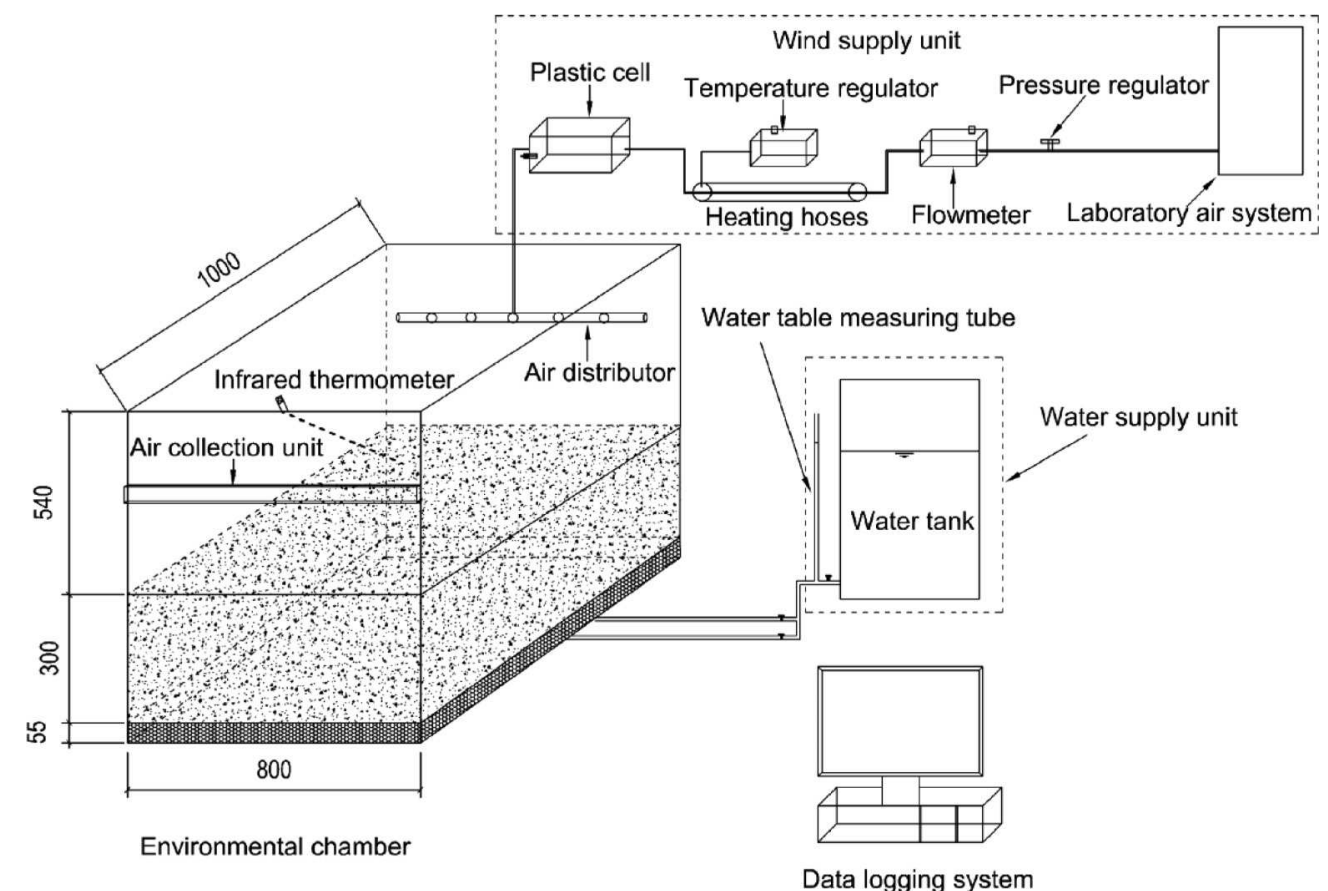

Table 1. Specification of the sensors used.

\begin{tabular}{|c|c|c|c|c|c|c|}
\hline Sensor & Manufacturer & Parameter measured & Range & Accuracy & Position & Number \\
\hline $\begin{array}{l}\text { High-capacity } \\
\text { tensiometer }\end{array}$ & ENPC & Matric suction & 0-1.5 MPa & - & $\begin{array}{l}\text { Soil surface and } \\
\text { chamber wall }\end{array}$ & 5 \\
\hline \multirow[t]{2}{*}{ T3111 transmitter } & Elcowa & Relative humidity & $0 \%-100 \%$ & $\pm 2.5 \%$ & $\begin{array}{l}\text { Chamber wall, wind } \\
\text { supply unit, and } \\
\text { air collection unit }\end{array}$ & 6 \\
\hline & & Temperature & $-30-+150{ }^{\circ} \mathrm{C}$ & $\pm 0.4{ }^{\circ} \mathrm{C}$ & $\begin{array}{l}\text { Chamber wall, wind } \\
\text { supply unit, and } \\
\text { air collection unit }\end{array}$ & 6 \\
\hline PT1000 & Correge & Temperature & $0-100{ }^{\circ} \mathrm{C}$ & $\pm 0.3{ }^{\circ} \mathrm{C}$ & Soil & 6 \\
\hline Thermistor (DO-35) & Radiospare & Temperature & $-40-+250{ }^{\circ} \mathrm{C}$ & $\pm 1.0 \%$ & Chamber wall & 5 \\
\hline $\begin{array}{l}\text { Infrared thermometer } \\
\text { (Pyropen-D) }\end{array}$ & Calex & Temperature & $-20-+250{ }^{\circ} \mathrm{C}$ & $\pm 1.0 \%$ & Chamber cover & 1 \\
\hline Flowmeter (MAS-3120) & Kobold & Air flow & $0-500 \mathrm{~L} / \mathrm{min}$ & $\pm 1.5 \%$ full scale & Wind supply unit & 1 \\
\hline $\begin{array}{l}\text { Anemometer } \\
\text { (Testo 435-2) }\end{array}$ & Testo & Wind speed & $0-20 \mathrm{~m} / \mathrm{s}$ & $\begin{array}{l} \pm(0.03 \mathrm{~m} / \mathrm{s}+5 \% \\
\text { measured value })\end{array}$ & $\begin{array}{l}50 \mathrm{~mm} \text { above soil } \\
\text { surface }\end{array}$ & 1 \\
\hline
\end{tabular}

$500 \mathrm{~L} / \mathrm{min}$. It was then heated in a heating tube to a temperature controlled by a temperature regulator. The temperature and relative humidity of this heated air were measured by a T3111 transmitter before being diffused in the chamber (i.e., inlet) through an air distributor (i.e., a perforated metal tube). After crossing the chamber (i.e., outlet), the air was gathered and the temperature and relative humidity were measured again. For control of the water table, it was necessary to adjust its level regularly by adding water into the tank.

Four soil water evaporation tests were conducted at various constant air rates and heating tube temperatures (see Table 2). Note that the heating tube temperature was much higher than that in the chamber, as can be seen later from the results. Tests 1 and 2 were carried out at similar air flow rates $(185 \mathrm{~L} / \mathrm{min}$ for test 1 and $172 \mathrm{~L} / \mathrm{min}$ for test 2), but different temperatures in the heating tube $\left(50{ }^{\circ} \mathrm{C}\right.$ for test 1 and $200{ }^{\circ} \mathrm{C}$ for test 2$)$. Tests 3 and 4 were conducted at the same lower air flow rate $(130 \mathrm{~L} / \mathrm{min})$ and different heating tube temperatures $\left(50{ }^{\circ} \mathrm{C}\right.$ for test 3 and $200{ }^{\circ} \mathrm{C}$ for test 4$)$.
The duration of tests 3 and 4 was much longer (17.5 days for test 3 and 30 days for test 4) than the 11.5 day duration of tests 1 and 2 . Note that the dry unit mass of sand is assumed to be unchangeable $\left(1.7 \mathrm{Mg} / \mathrm{m}^{3}\right)$ during the four evaporation tests.

Determination of the evaporation rate is based on the water vapor balance, as follows:

$$
E_{\mathrm{a}}=(86400) Q\left(H_{\mathrm{a}-\text { outlet }}-H_{\mathrm{a} \text {-inlet }}\right) /\left(\rho_{\mathrm{w}} A\right)
$$

where $E_{\mathrm{a}}$ is the actual evaporation rate ( $\mathrm{mm} /$ day); $Q$ is the air flow rate through the chamber $(\mathrm{L} / \mathrm{s}), H_{\mathrm{a}-\text { outlet }}$ and $H_{\mathrm{a} \text {-inlet }}$ are the absolute humidity $\left(\mathrm{Mg} / \mathrm{m}^{3}\right)$ at the outlet and inlet, respectively; $\rho_{\mathrm{w}}$ is the density of water $\left(\mathrm{Mg} / \mathrm{m}^{3}\right)$, and $A$ is the area of the evaporative surface exposed in the chamber $\left(\mathrm{m}^{2}\right)$.

The absolute humidity $\left(H_{\mathrm{a}}\right)$ is calculated using eq. (2):

$$
H_{\mathrm{a}}=0.622 e_{\mathrm{a}} /\left(1000 R T_{\mathrm{a}}\right)
$$


Fig. 3. Sketch of arrangement of the sensors.

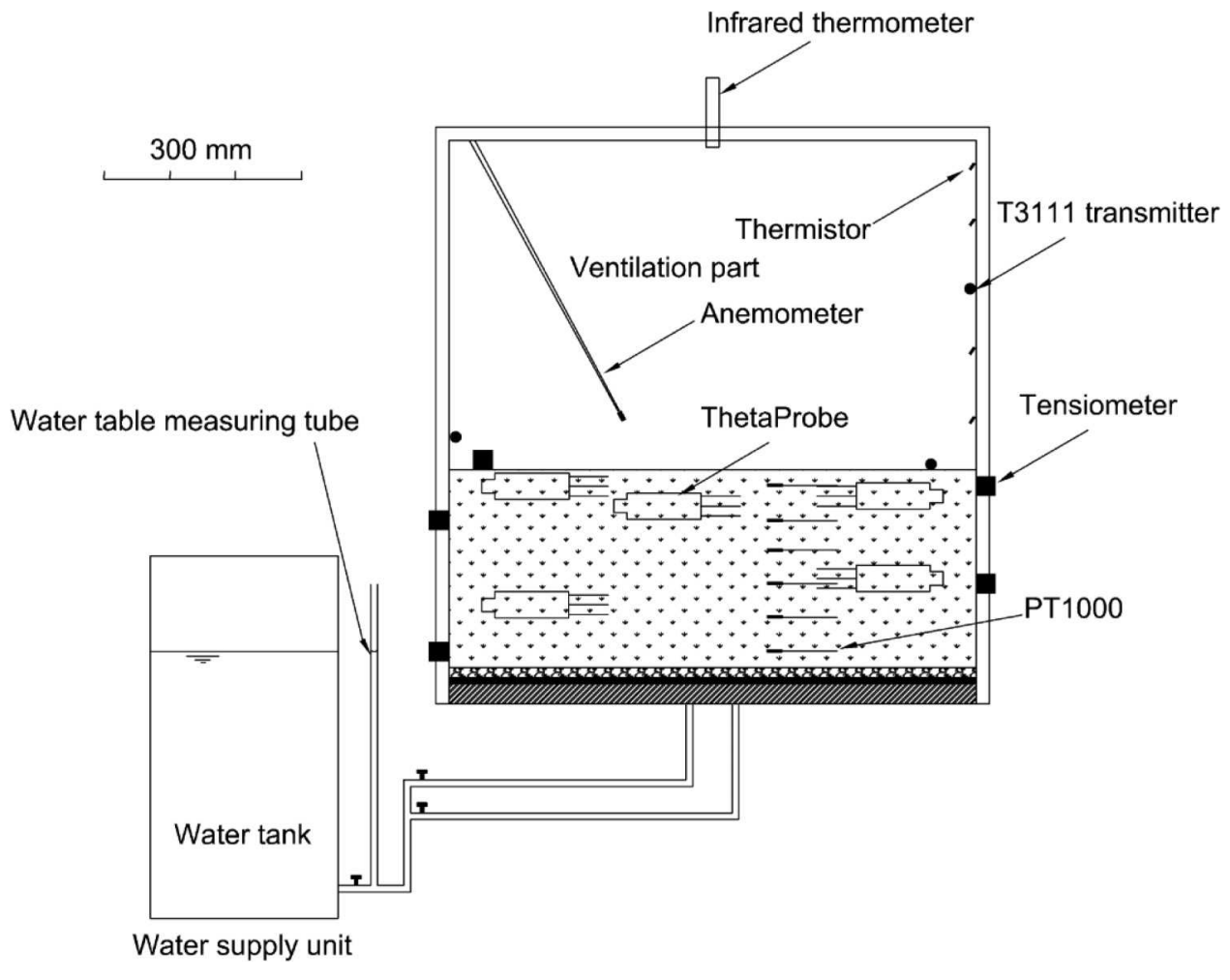

Fig. 4. Soil compaction and sensor installation: (a) soil compaction, (b) ThetaProbe installation in the zone of $60 \mathrm{~mm}$ depth, (c) T3111 transmitter and thermistor installation, and $(d)$ infrared thermometer installation.

(a)

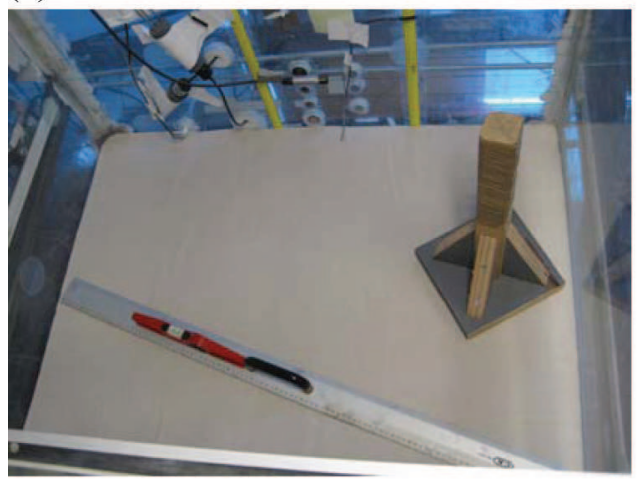

(c)

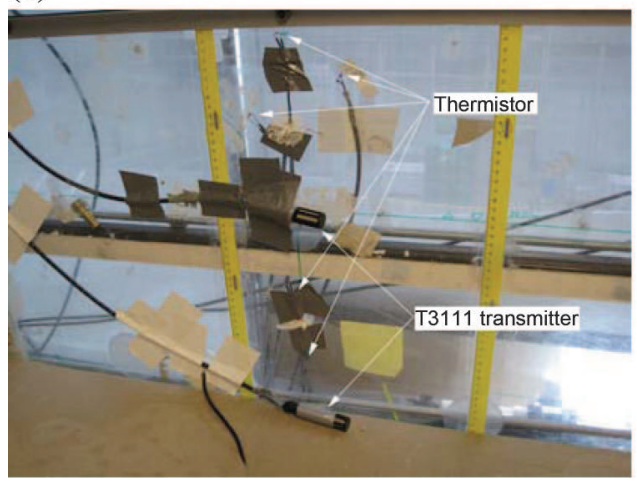

(b)

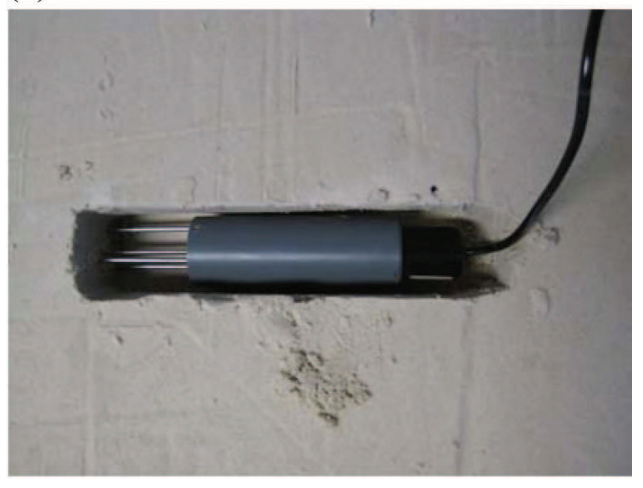

(d)

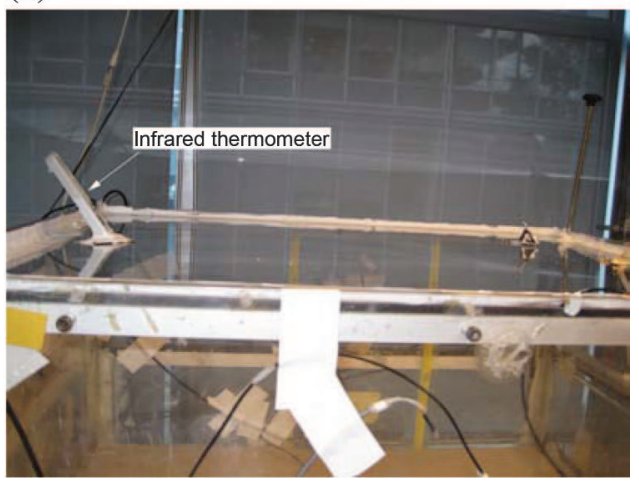

- Published by NRC Research Press 
Table 2. Test program.

\begin{tabular}{llcl}
\hline $\begin{array}{l}\text { Test } \\
\text { number }\end{array}$ & $\begin{array}{l}\text { Air flow } \\
\text { rate }(\mathrm{L} / \mathrm{min})\end{array}$ & $\begin{array}{l}\text { Temperature } \\
\text { in heating } \\
\text { tube }\left({ }^{\circ} \mathrm{C}\right)\end{array}$ & $\begin{array}{l}\text { Test } \\
\text { duration } \\
\text { (days) }\end{array}$ \\
\hline 1 & 185 & 50 & 11.5 \\
2 & 172 & 200 & 11.5 \\
3 & 130 & 50 & 17.5 \\
4 & 130 & 200 & 30 \\
\hline
\end{tabular}

where $e_{\mathrm{a}}$ is the vapor pressure $(\mathrm{Pa}), \mathrm{R}$ is the gas constant $(287.04 \mathrm{~J} /(\mathrm{kg} \cdot \mathrm{K}))$, $\mathrm{T}_{\mathrm{a}}$ is the air temperature (K), 0.622 is the ratio of the molecular weight of water to that of dry air. The vapor pressure, $e_{\mathrm{a}}$, is determined by eq. (3)

$$
e_{\mathrm{a}}=e_{\mathrm{sat}} H_{\mathrm{r}} / 100
$$

where $e_{\text {sat }}$ is the saturated vapor pressure $(\mathrm{Pa})$ and $H_{\mathrm{r}}$ is the air relative humidity (\%).

The saturated vapor pressure $\left(e_{\text {sat }}\right)$ is deduced from eqs. (4) and (5) (Brutsaert 1988)

$$
\begin{array}{r}
e_{\text {sat }}=(101325) \exp \left(13.3185 t_{\mathrm{R}_{\mathrm{a}}}-1.9760 t_{\mathrm{R}_{\mathrm{a}}}^{2}-0.6445 t_{\mathrm{R}_{\mathrm{a}}}^{3}\right. \\
\left.-0.1299 t_{\mathrm{R}_{\mathrm{a}}^{4}}^{4}\right)
\end{array}
$$

$$
t_{\mathrm{R}_{\mathrm{a}}}=1-373.15 / \mathrm{T}_{\mathrm{a}}
$$

Note that this method was also used by Mohamed et al. (2000) and Aluwihare and Watanabe (2003).

\section{Results and discussion}

\section{Air flow rate}

Figure 5 depicts the variations of air flow rate versus elapsed time during the four drying tests. It can be seen that some fluctuation as high as $\pm 5 \mathrm{~L} / \mathrm{min}$ exist around a constant average value in test 1 (Fig. 5a), test 2 (Fig. $5 b$ ), and test 3 (Fig. 5c). The larger fluctuation in test 4 (Fig. $5 d$ ) was due to a technical problem related to the compressed air system in the laboratory. It is noted that the corresponding average wind speeds at $50 \mathrm{~mm}$ above the soil surface are $0.5,0.46$, 0.34 , and $0.34 \mathrm{~m} / \mathrm{s}$ in tests $1,2,3$, and 4 , respectively.

\section{Air temperature}

Figure 6 shows air temperatures at the inlet and outlet of the chamber as well as in the laboratory, the inlet temperature being the highest. When the heating tube temperature is high (i.e., $200{ }^{\circ} \mathrm{C}$ in tests 2 and 4, see Figs. $6 b$ and $6 d$ ), the laboratory temperature is lower than the outlet one. By contrast, when the heating tube temperature is low (i.e., $50^{\circ} \mathrm{C}$ in test 1 s and 3, see Figs. $6 a$ and $6 c$ ), the phenomenon is reversed.

Evolutions of air temperature at different elevations in the chamber are presented in Fig. 7. Note that the positions with similar air temperatures are termed as "other heights". On the whole, at the same heating tube temperature, the higher the air flow rate the lower the air temperature in the chamber. Indeed, the air temperature in test $3\left(17.5\right.$ to $21.5^{\circ} \mathrm{C}$, see Fig. $7 c$ ) at $130 \mathrm{~L} / \mathrm{min}$ air flow rate is higher than that in test $1\left(16\right.$ to $20.5^{\circ} \mathrm{C}$, see Fig. $\left.7 a\right)$ at $185 \mathrm{~L} / \mathrm{min}$. The same trend can be observed when comparing test 2 to test 4 (see Figs. $7 b$ and $7 d$ ). Furthermore, at a similar air flow rate, the air temperature increases over time when the heating tube temperature is as high as $200{ }^{\circ} \mathrm{C}$ (i.e., tests 2 and 4). However, when the heating tube temperature is as low as $50{ }^{\circ} \mathrm{C}$ (i.e., tests 1 and 3 ), the air temperature declines initially, and then goes up and down. Compared to the temperatures at inlet (see Fig. 6), the temperatures in the chamber vary in the same fashion (see Fig. 7), indicating that the air temperatures inside the cham- ber are strongly influenced by the inlet temperature. It is also observed that air temperature shows a sharp increasing trend by the end of test 3 and in the middle of tests 2 and 4 .

The inlet temperature is one of the controlled parameters in the four tests (see Fig. 6). Its values (i.e., 22, 24, 47, and $56^{\circ} \mathrm{C}$ ) depend on both the heating tube temperature and air flow rate. Indeed, when the air flow rate is similar, a high heating tube temperature produces high inlet temperature (e.g., the inlet air temperature in test 4 is higher than in test 3 ). When the heating tube temperature is fixed, the inlet temperature is higher at a lower air flow rate (e.g., the inlet air temperature in test 3 is higher than in test 1 ). In addition, the temperature drops from inlet to outlet. This suggests that the soil water evaporation in the chamber is an energyconsuming process. Inside the environmental chamber, the air adsorbs energy from hot air, leading to an increase of its temperature (see Fig. 7). As water vaporization consumes energy and cools the surrounding medium, the temperature of air close to the soil surface (i.e., $80 \mathrm{~mm}$ height) is affected and exhibits the lowest value. Under low heating tube temperatures (see Figs. $7 a$ and $7 c$ ), water evaporation consumes more energy than air heating, thereby cooling both air and soil. Consequently, air temperatures decrease during the first 0.5 and 0.7 days in tests 1 and 3, respectively (see Figs. $7 a$ and $7 c$ ). At high heating tube temperatures (see Figs. $7 b$ and $7 d$ ), the energy from hot air allows both water evaporation and air heating. Therefore, the air temperature exhibits a gradual increase in tests 2 and 4 , exceeding the laboratory temperature.

\section{Soil temperature}

Evolutions of soil temperature at different positions are presented in Fig. 8. The positions with similar temperatures are termed as "other depths". Two distinct evolutions can be identified: the soil temperatures show a gradual increase at high heating tube temperatures (i.e., tests 2 and 4, see Figs. $8 b$ and $8 d$ ), while at low heating tube temperature (i.e., tests 1 and 3, see Figs. $8 a$ and $8 c$ ) a decrease is observed at the beginning. In addition, soil temperatures at high air flow rates are lower than that at low air flow rates when the heating temperature is the same. Indeed, at a heating tube temperature of $50{ }^{\circ} \mathrm{C}$ the temperature values vary from 10.5 to $18{ }^{\circ} \mathrm{C}$ in test 1 at $185 \mathrm{~L} / \mathrm{min}$ (see Fig. 8a) while they change within the range $13-20.5^{\circ} \mathrm{C}$ in test 3 at $130 \mathrm{~L} / \mathrm{min}$ (see Fig. $8 \mathrm{c}$ ). A similar phenomenon is observed in tests 2 (see Fig. $8 b$ ) and 4 (see Fig. $8 d$ ), both at a $200{ }^{\circ} \mathrm{C}$ heating tube temperature, despite the unstable imposed air flow in test 4 . Furthermore, the soil surface temperature is the lowest at low heating tube temperatures (i.e., tests 1 and 3 ) while it is the highest at high heating tube temperatures (i.e., tests 2 and 4). The soil temperature at different depths increases quickly by the end of tests 1 and 3 (see Figs. $8 a$ and $8 c$, respectively) or in the middle of tests 2 and 4 (see Figs. $8 b$ and $8 d$, respectively), especially at the soil surface. In addition, the evolution of soil temperatures follows the one of air temperatures.

The evolutions of soil temperature are also evaporation dependent (see Fig. 8). Indeed, comparison with the evolutions of air temperature (see Fig. 7) shows that the changes of soil and air temperatures are similar (i.e., both of them decrease at the initiation of evaporation, and then go up and down), suggesting that the energy for evaporation is supplied by both air and soil at low heating tube temperatures. At high heating tube temperatures (i.e., tests 2 and 4), soil temperatures are elevated as air temperatures because the high temperature air flow provides more energy than required for water evaporation. Furthermore, the soil temperatures decrease after the initiation of evaporation and then increase along with the decline of evaporation rate at low heating tube temperatures (Figs. $8 a$ and $8 c$ ). A similar trend was observed in the column drying test conducted by Wilson (1990) and Wilson et al. (1994) and in the column evaporation test under controlled air conditions performed by Yanful and Choo (1997). 
Fig. 5. Variations of air flow rate: (a) test $1,(b)$ test 2 , (c) test 3, and (d) test 4.
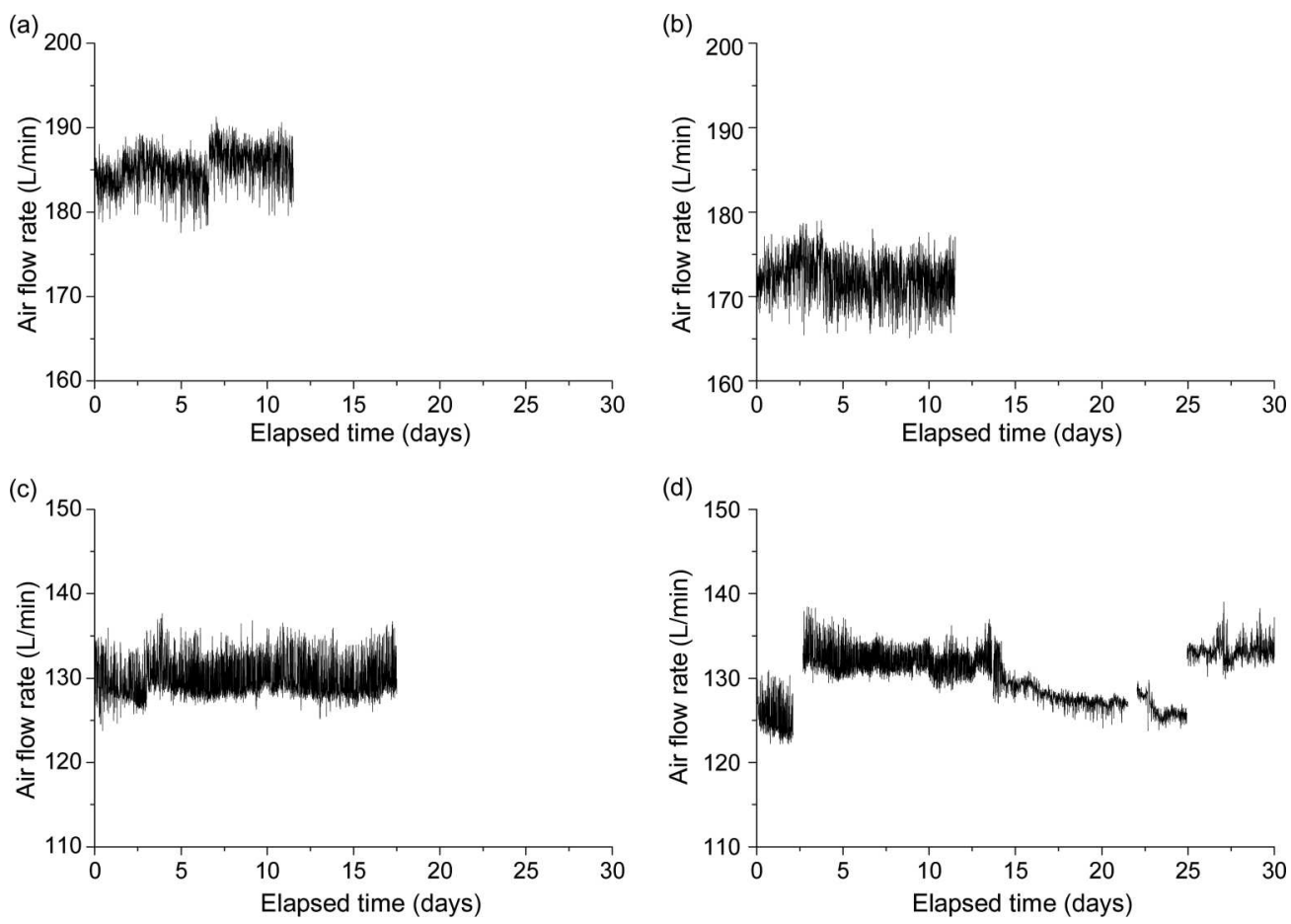

Fig. 6. Evolutions of air temperature at inlet and outlet of the chamber as well as in the laboratory: (a) test 1, (b) test 2, (c) test 3 , and (d) test 4 .
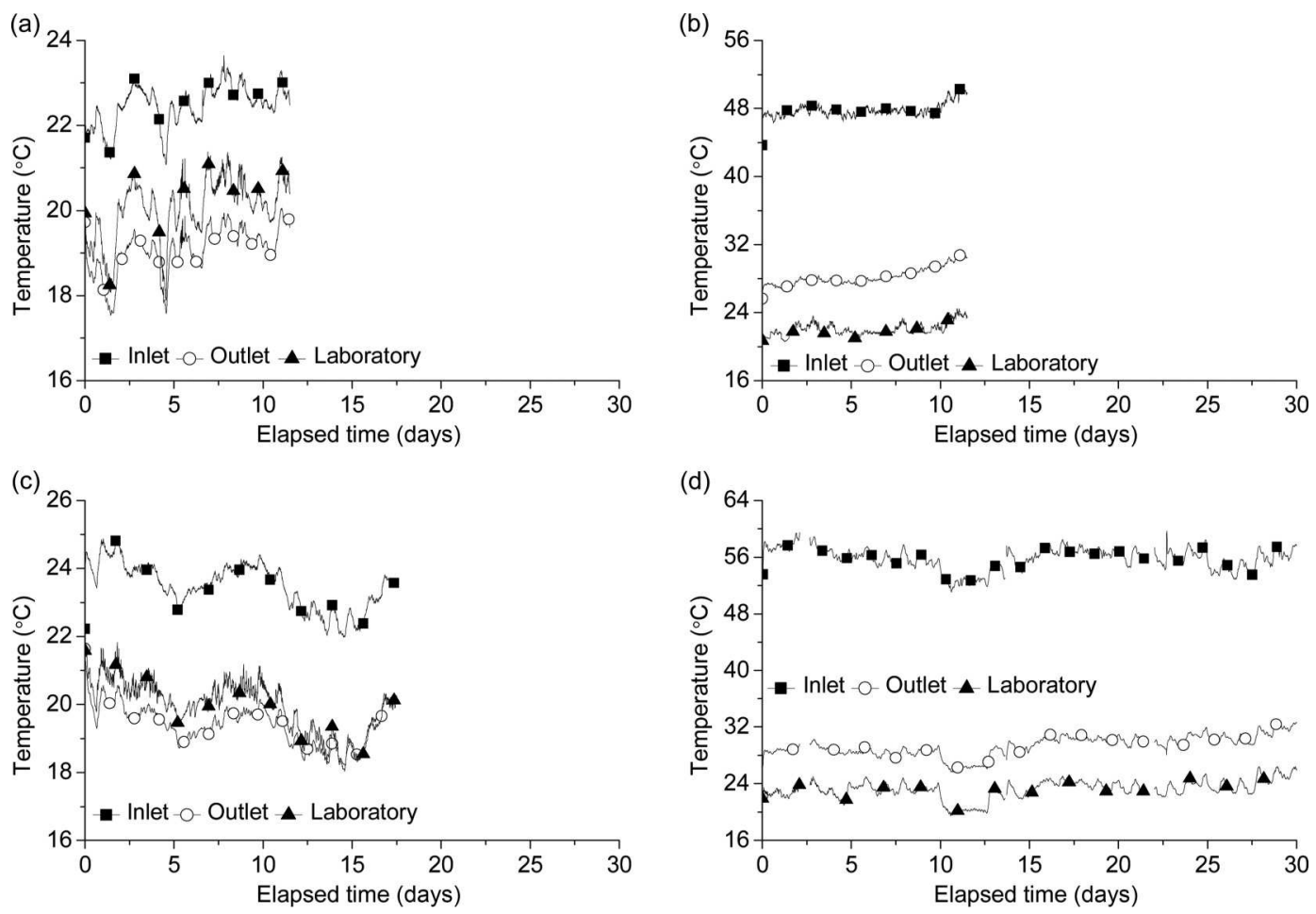

\section{Air-soil temperature profile}

To further analyze the evolutions of temperature inside the chamber, the recorded air and soil temperatures are used to establish the air-soil temperature profiles (Fig. 9). The highest air temperature is observed at the elevation corresponding to the level of air inlet (i.e., air distributor). The air temperature decreases from this position to the position close to the chamber cover and it also declines from this position to the soil surface. The

temperature at the soil surface is the lowest value under low heating tube temperatures (see Figs. $9 a$ and $9 c$ ) while this phenomenon is not observed in the case of high heating tube temperatures (see Figs. $9 b$ and $9 d$ ). On the other hand, the soil temperatures increase progressively over depth under low heating tube temperatures (see Figs. $9 a$ and $9 c$ ) while it decreases under high heating tube temperatures (see Figs. $9 b$ and $9 d$ ). Note that the temperatures inside the soil column (i.e., below $25 \mathrm{~mm}$ depth) are similar 
Fig. 7. Evolutions of air temperature at different elevations: (a) test $1,(b)$ test $2,(c)$ test 3 , and $(d)$ test 4 .

(a)

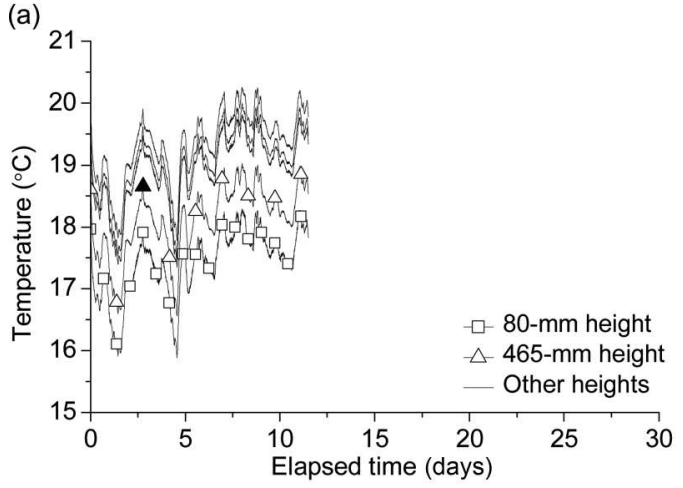

(c)

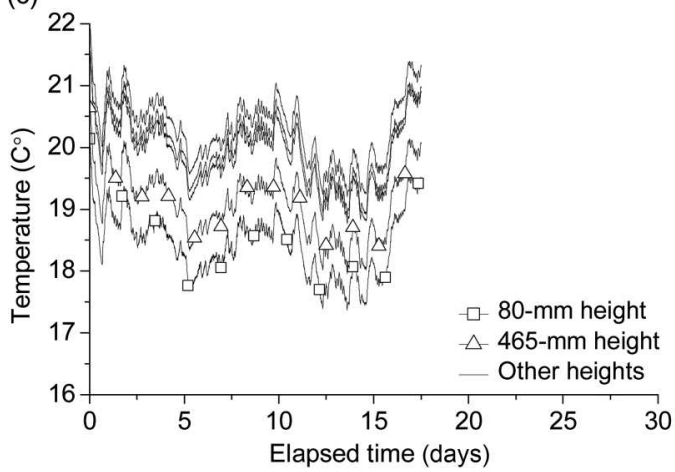

(b)

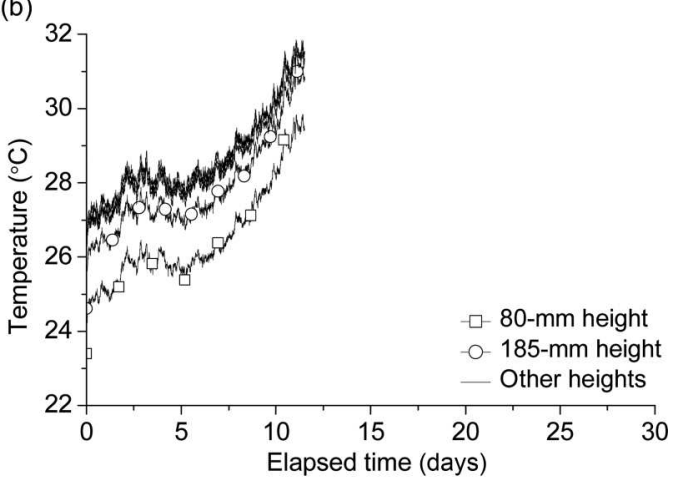

(d)

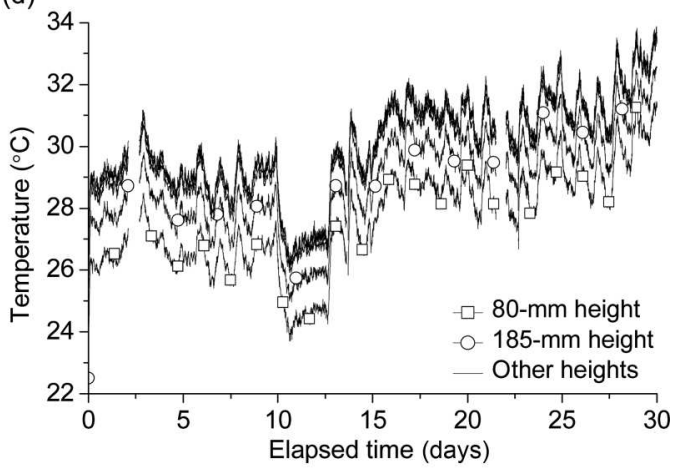

Fig. 8. Evolutions of soil temperature at different positions: $(a)$ test $1,(b)$ test $2,(c)$ test 3 , and $(d)$ test 4 .
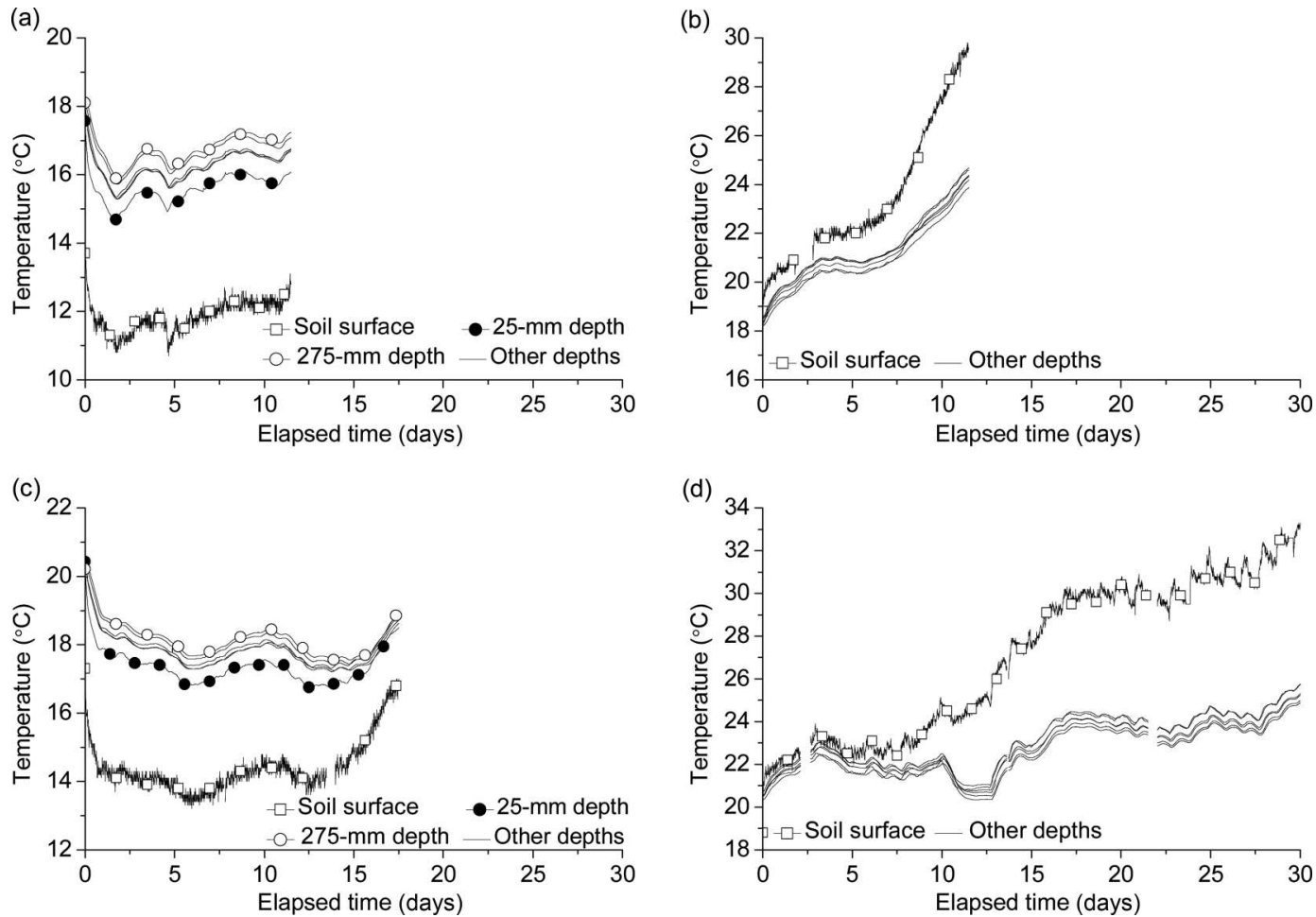

for the four tests. Two sharp but quite opposite temperature gradients are observed between the $80 \mathrm{~mm}$ height, soil surface, and $25 \mathrm{~mm}$ depth under low heating tube temperatures. By contrast, only one temperature gradient is identified under high heating tube temperatures. Note that the initial soil temperature distribu-

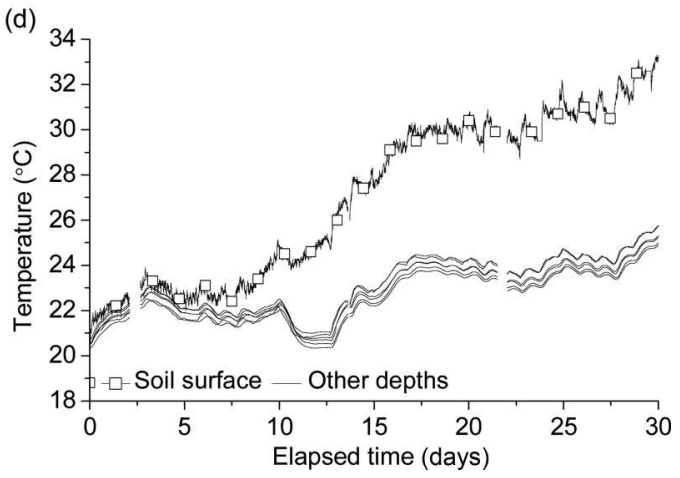

tion at the beginning of evaporation in different tests can also be identified from the profiles: for test 1 , the soil temperature at the surface is $13.7^{\circ} \mathrm{C}$; it increases to $17.6^{\circ} \mathrm{C}$ at $25 \mathrm{~mm}$ depth, and to $18.1^{\circ} \mathrm{C}$ at $275 \mathrm{~mm}$ depth. For test 2 , it decreases from $18.8^{\circ} \mathrm{C}$ at the soil surface to $18.4{ }^{\circ} \mathrm{C}$ at $275 \mathrm{~mm}$ depth. For test 3, it increases 
Fig. 9. Profiles of air-soil temperature: $(a)$ test $1,(b)$ test $2,(c)$ test 3 , and $(d)$ test4.

(a)

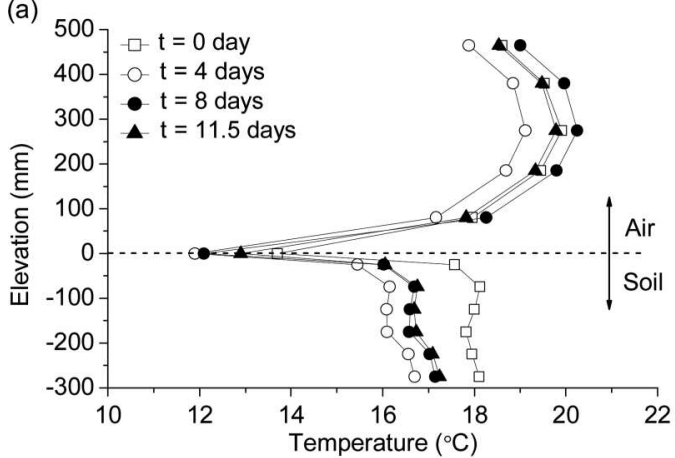

(c)

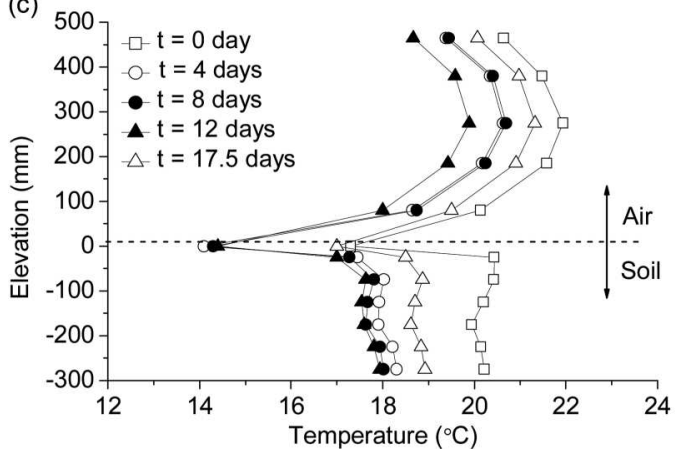

from $17.3^{\circ} \mathrm{C}$ at the soil surface to $20.2{ }^{\circ} \mathrm{C}$ at $275 \mathrm{~mm}$ depth. For test 4 , it varies between $18.8{ }^{\circ} \mathrm{C}$ (at the surface) and $20.5{ }^{\circ} \mathrm{C}$ (at $275 \mathrm{~mm}$ depth).

The observed results can be explained as follows. At the beginning of the evaporation process, the water at the soil surface firstly evaporates and the lowest temperature appears in this location (e.g., tests 1, 3, and 4). Further evaporation leads the soil surface to become dry and the evaporation front progresses into a deeper position; that is, the lowest temperature position is deeper. During this evaporation process, the water loss increases soil resistance to evaporation, thus decreasing the evaporation rate. The energy consumed by evaporation also declines. As a result, more energy is available for increasing soil and air temperatures. This explains the quick increase of soil and air temperatures when the evaporation rate is low (e.g., in tests 2,3 , and 4) or when the evaporation duration is long. Therefore, we can deduce that if longer drying is allowed in test 3 , the lowest temperature will not be at the soil surface.

\section{Air relative humidity}

The changes of air relative humidity in the chamber are presented in Fig. 10. All values at various elevations decline over time. Relative humidity at the soil surface presents the highest value while the one at the inlet shows the lowest. Furthermore, values at the outlet, at $50 \mathrm{~mm}$, and $275 \mathrm{~mm}$ height are very similar. In general, the evolution of relative humidity at various positions except the inlet can be divided into three stages: $(i)$ initial decrease stage - the relative humidity decreases slowly in the first 10 days under low heating tube temperatures, and in the first 6 to 8 days under high heating tube temperatures; (ii) quick decline stage; and (iii) stabilization stage with a quite low decrease rate. All these three stages appear clearly in test 4 (see Fig. 10d). The first two stages appear in tests 2 and 3 (see Figs. $10 b$ and 10c) while only the first stage appears in test 1 (see Fig. 10a). For test 1 , the imposed air relative humidity at inlet is low and keeps a constant value around $6.5 \%$ while the outlet air relative humidity decreases from $46 \%$ to $33 \%$ over time. The imposed relative humidity at the inlet is around $1.5 \%, 3.5 \%$, and lower than $1 \%$ in tests 2,3 , and 4 , respec-
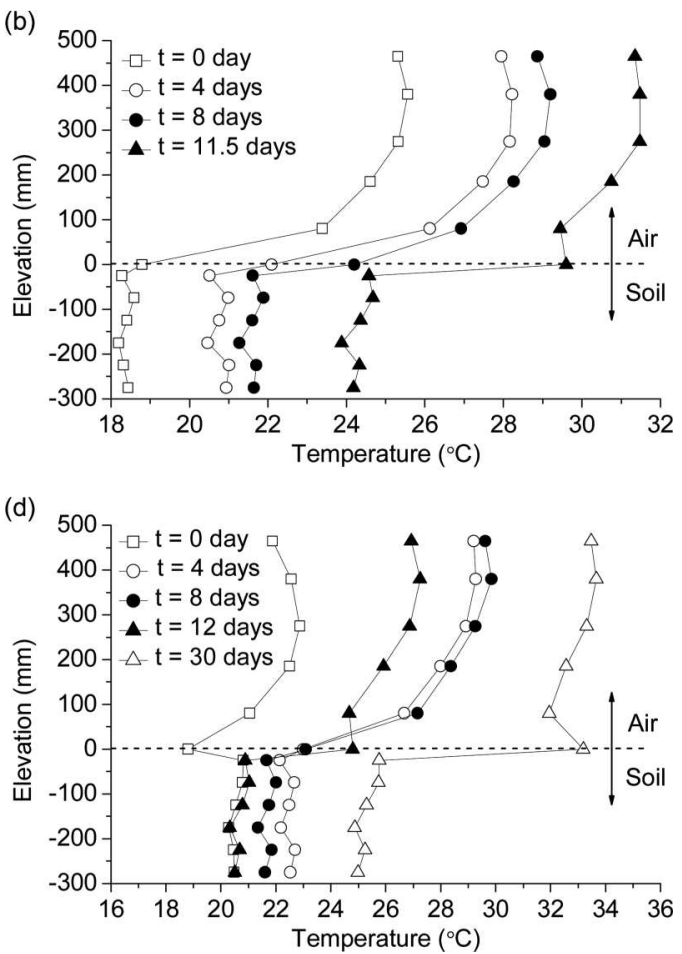

tively, whereas the corresponding values at the outlet vary from $33 \%$ to $12.4 \%, 50 \%$ to $20 \%$, and $35 \%$ to $8 \%$, respectively. Note that the surface relative humidity does not correspond exactly to the surface position but at $5 \mathrm{~mm}$ above the soil surface due to the dimensions of the sensor.

The values of air relative humidity at different elevations clearly reflect the evaporation process. Because of water evaporation from the soil, the air relative humidity near the soil surface is higher than at other elevations (see Fig. 10). This relative humidity difference is sustained when water supply for evaporation is sufficient (e.g., from $t=0$ to 9 days in test 3). Along with the evaporation process, the soil surface resistance to evaporation increases and the amount of water vapor entering the air decreases. Thus, the relative humidity difference at different elevations decreases. Eventually, water evaporation will cease when the soil vapor pressure becomes equal to that of the surrounding air (Yanful and Choo 1997). On the other hand, from the evolutions of relative humidity, the effects of air temperature and air flow rate on evaporation can also be observed: at similar air flow rates, the higher the heating tube temperature the lower the relative humidity inside the chamber. At the same heating tube temperature, a lower air flow rate gives rise to only a slightly higher relative humidity.

\section{Soil volumetric water content}

The changes of volumetric water content are shown in Fig. 11. As expected, the volumetric water content in the near-surface zone (i.e., from soil surface to $60 \mathrm{~mm}$ depth) firstly decreases in all tests, followed by a decrease at $125 \mathrm{~mm}$ depth, while the value at $275 \mathrm{~mm}$ depth remains unchanged. Taking test 1 as an example, the volumetric water content in the soil surface zone declines from $29.3 \%$ to $8.9 \%$ at $25 \mathrm{~mm}$ depth and from $31.7 \%$ to $13.8 \%$ at $55 \mathrm{~mm}$ depth. In a deeper zone at $125 \mathrm{~mm}$ depth, the value is constant in the first 9.5 days, and then decreases from $31.4 \%$ to $28.6 \%$ at the end of the test. However, the value at $275 \mathrm{~mm}$ depth remains $34.5 \%$. Note that the volumetric water content at a saturated state is $35.6 \%$. The evolution of volumetric water content in the near-surface zone also follows three stages: (i) a decrease with 
Fig. 10. Evolutions of air relative humidity at different positions in the chamber: $(a)$ test $1,(b)$ test $2,(c)$ test 3 , and $(d)$ test 4.
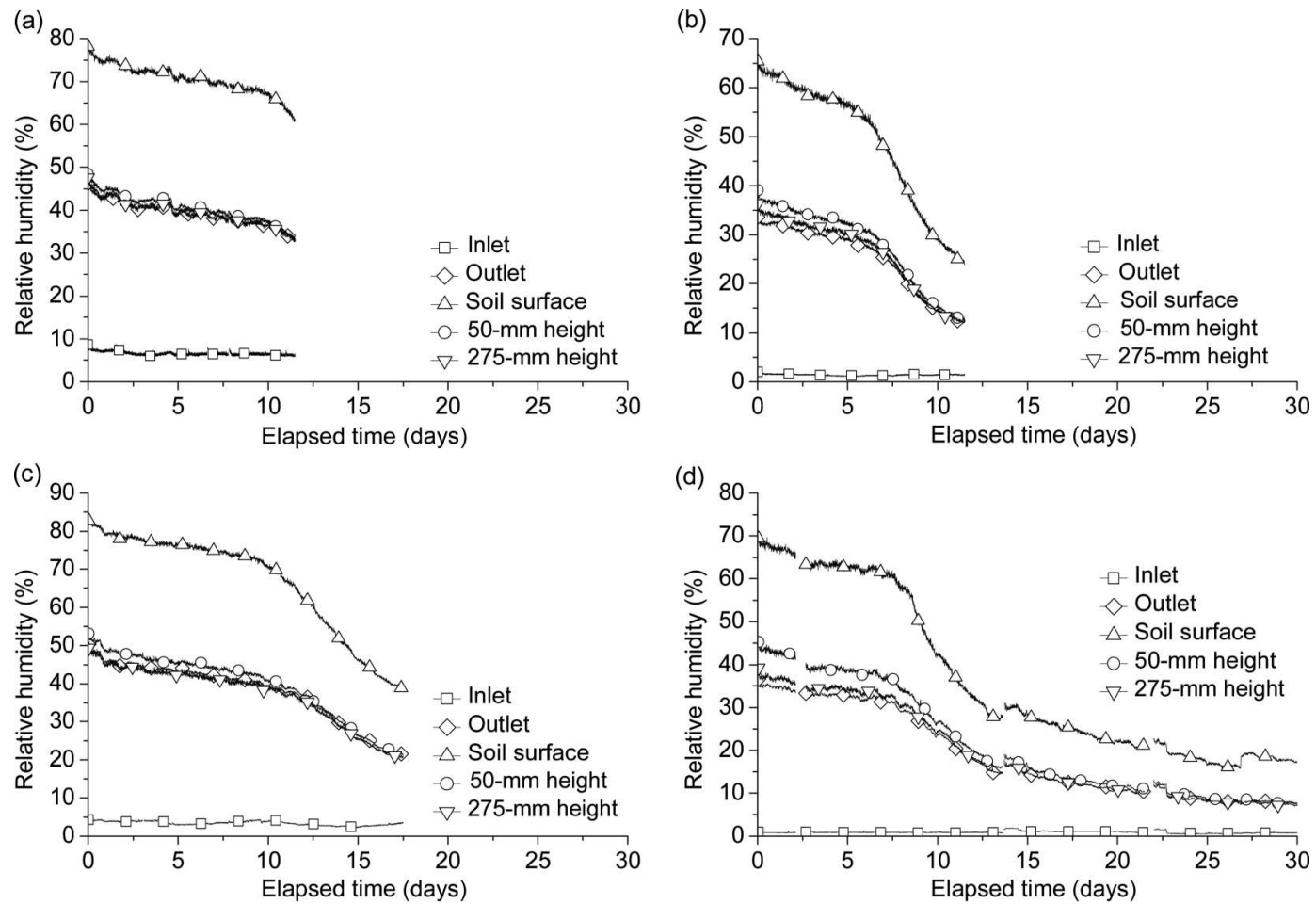

Fig. 11. Evolutions of volumetric water content at different depths: $(a)$ test $1,(b)$ test $2 .(c)$ test 3 , and $(d)$ test 4.
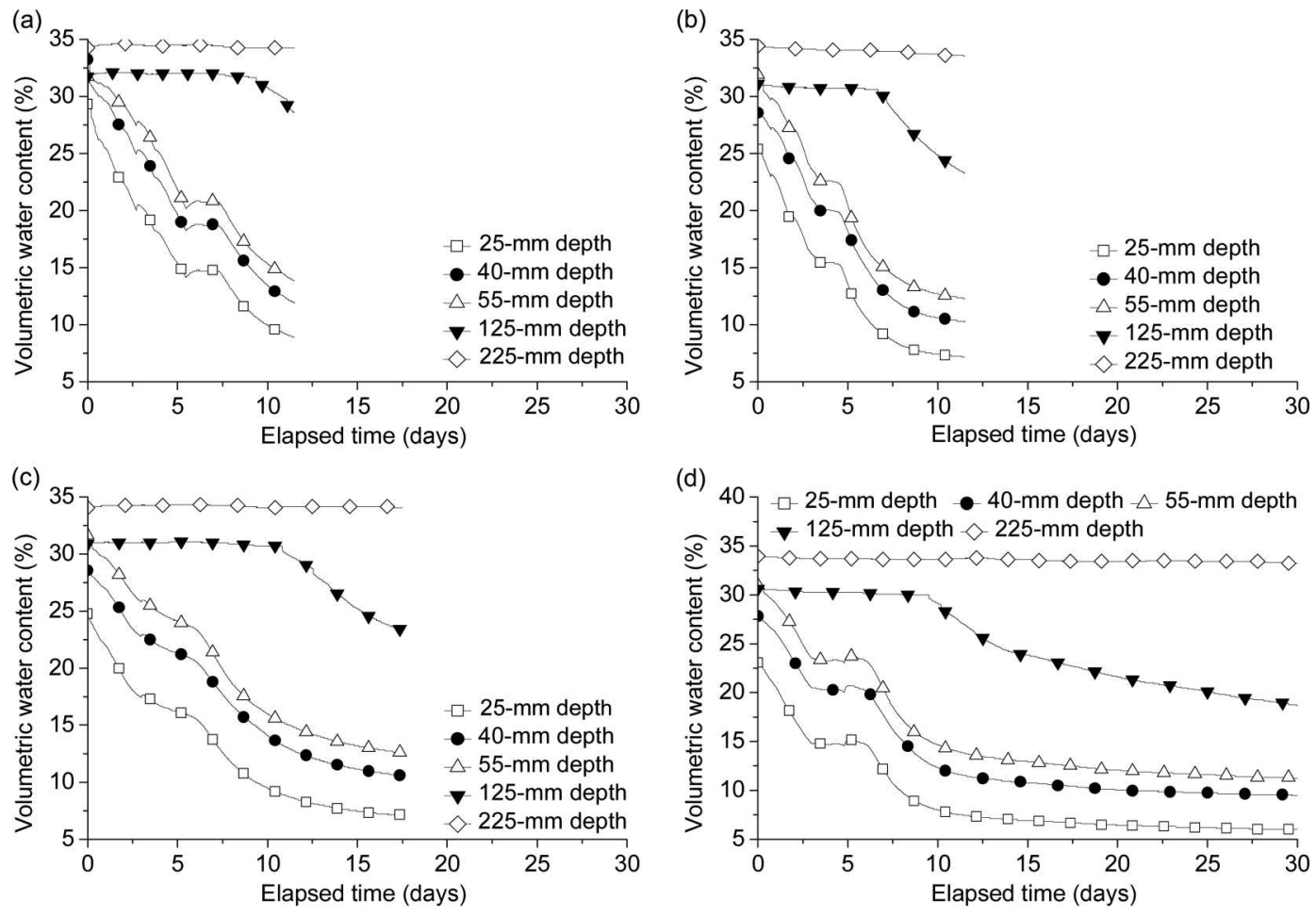

constant rate, (ii) a short stage with constant values, and (ii) a second decline at a decreasing rate.

The evolutions of volumetric water content at various depths are depicted by Fig. 12. This contour map allows visualization of the drying advance in the soil column. On the whole, all contour lines go into a deeper position over time except the $35 \%$ line. Furthermore, the lower the water content the later the line appears.

For instance, in test 1 , the $30 \%$ contour line is at $25 \mathrm{~mm}$ depth in the beginning; its depth increases quickly and reaches $110 \mathrm{~mm}$ in the first 3.5 days. It continues to increase at a very low rate, but at $t=$ 11 days it increases sharply and reaches $150 \mathrm{~mm}$ at the end of the test. The contour line of $30 \%$ almost remains constant at $110 \mathrm{~mm}$ depth from $t=3.5$ to 11 days, suggesting that water loss occurs only in the zone above this depth. In terms of variation of 
Fig. 12. Contour map of evolutions of volumetric water content at different times: $(a)$ test $1,(b)$ test $2,(c)$ test 3 , and $(d)$ test 4.
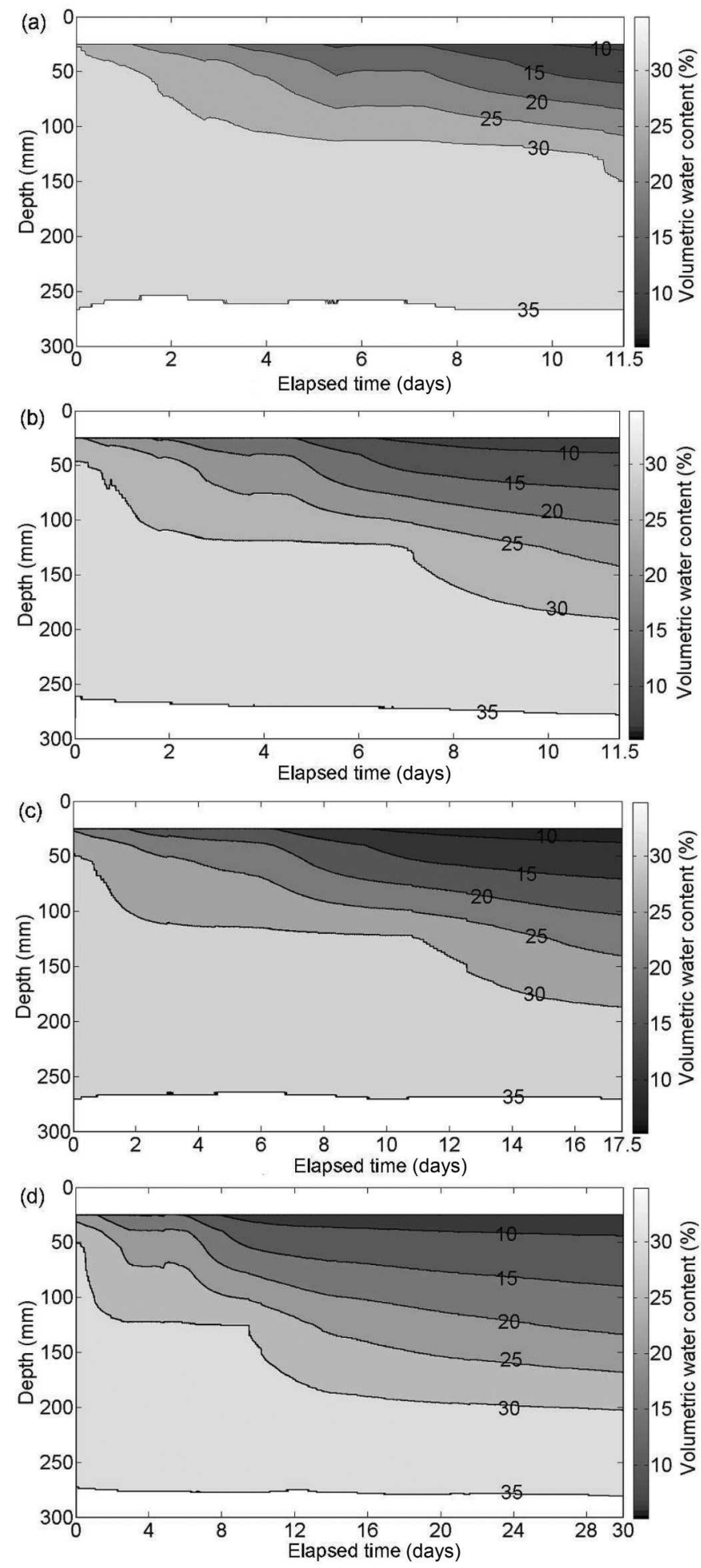

volumetric water content, it decreases from $30 \%$ to $25 \%$ in the first 1.2 days at $25 \mathrm{~mm}$ depth, decreases to $20 \%$ at $t=3.2$ days, to $15 \%$ at $t=5.2$ days, and to $10 \%$ at $t=10$ days. At the end of the test, it becomes lower than $10 \%$. Similar observations can be made for the other tests.

The profiles of volumetric water content for different tests are shown in Fig. 13. A clear water loss can be observed due to evaporation. In general, a linear relationship between water content and depth in the near-surface zone (i.e., 25, 40, and $55 \mathrm{~mm}$ depths) can be observed. Moreover, this linear relationship also develops toward deeper zones. Indeed, in test 3 (see Fig. 13c) the linear relationship exists at three positions, i.e., 25, 40, and $55 \mathrm{~mm}$ depths, with a slope of about $0.23 \% / \mathrm{mm}$. This relationship also exists from 25 to $225 \mathrm{~mm}$ depth at $t=17.5$ days. It is noted that the volumetric water content distribution over depth at the beginning of the four evaporation tests can also be observed: for test 1 , the volumetric water contents at 25,40 , and $55 \mathrm{~mm}$ depths are $29.3 \%, 33 \%$, and $32 \%$, respectively. The values in the deeper zone (below $55 \mathrm{~mm}$ depth) increase over depth from 32\% to $35.6 \%$. For test 2 , the values of volumetric water content increase from $25.4 \%$ at $25 \mathrm{~mm}$ depth to $34.4 \%$ at $225 \mathrm{~mm}$ depth. For test 3, the volumetric water content values also increase from $24.8 \%$ at $25 \mathrm{~mm}$ depth to $34.1 \%$ at $225 \mathrm{~mm}$ depth. For test 4, the values increase from $23.1 \%$ at $25 \mathrm{~mm}$ depth to $34 \%$ at $225 \mathrm{~mm}$ depth. The volumetric water content at the soil bottom in the four tests is close to the saturated value, $35.6 \%$.

Basically, soil water evaporation results in a decrease of water content. In the tests performed, the volumetric water content in the near surface zone declines quickly at the initiation of evaporation and then decreases gradually. Furthermore, the deeper zone starts to lose water only when the evaporation lasts a long time (see Fig. 11). This phenomenon can be explained by the evolution of soil resistance to evaporation (van de Griend and Owe 1994; Wythers et al. 1999). A similar decreasing trend was observed by Wythers et al. (1999) in their field evaporation experiment on loams.

The results of volumetric water content from the four tests show that the evaporation from bare soil occurs mainly in the near surface zone (e.g., within a depth of $55 \mathrm{~mm}$ ). This agrees with the observation by Wythers et al. (1999). Furthermore, the evolution at deeper positions suggests that the bottom soil will become dry if the evaporation continues and if there is no water table. The contour map (see Fig. 12) clearly indicates this trend. Note that the linear relationship of soil water content in the near-surface zone (see Fig. 13) can be used for determining the surface water content by extrapolation.

\section{Matric suction}

The evolutions of suction over time are presented in Fig. 14 for the four tests. It can be observed that suction increases over time for all positions, indicating the progress of the evaporation process. It also decreases over depth, with the value on the soil surface being the highest. In test 1, only the suctions at the soil surface (i.e., $5 \mathrm{~mm}$ depth), $77 \mathrm{~mm}$ depth, and $276 \mathrm{~mm}$ depth are monitored. The soil surface suction grows in the beginning from 13 to $240 \mathrm{kPa}$ at $t=8$ days, and reaches the limit of the tensiometer (1.5 MPa) 1 day later. The suctions at the other two positions are nearly the same, and the tensiometer at $77 \mathrm{~mm}$ depth fails due to cavitation after 8 days. In test 2 , suction at the soil surface (i.e., $10 \mathrm{~mm}$ depth) increases quickly from $14 \mathrm{kPa}$ at $t=0$ days to $46 \mathrm{kPa}$ at $t=8$ days, and reaches the limit of the tensiometer (1.5 MPa) a few hours later. At $77 \mathrm{~mm}$ depth, the suction is slightly higher than at $173 \mathrm{~mm}$ depth. The lowest matric suction is found at $276 \mathrm{~mm}$ depth. In test 3 , suctions were recorded at the same positions as in test 1 , and the data in the first 0.7 days was not recorded. The suction at soil surface (i.e., $10 \mathrm{~mm}$ depth) grows from 5 to $22 \mathrm{kPa}$. The value at $77 \mathrm{~mm}$ depth is higher than at the bottom (i.e., $276 \mathrm{~mm}$ depth). For test 4, the surface suction (i.e., $10 \mathrm{~mm}$ depth) varies from 17 to $67 \mathrm{kPa}$ during the first 17.5 days. The values at 20 and $25 \mathrm{~mm}$ depths were measured in this test and the tensiometers reached their limits at $t=13$ and 17.7 days, respectively. The lowest suction is observed at the bottom and the value at $173 \mathrm{~mm}$ depth is close to the bottom one. Note that the suction measurement was disturbed from $t=2.1$ to 2.7 days due to some technical problems. The tensiometers at 173 and $276 \mathrm{~mm}$ depth did not work correctly during this test and stopped 
Fig. 13. Profiles of volumetric water content: $(a)$ test $1,(b)$ test $2,(c)$ test 3 , and $(d)$ test 4.
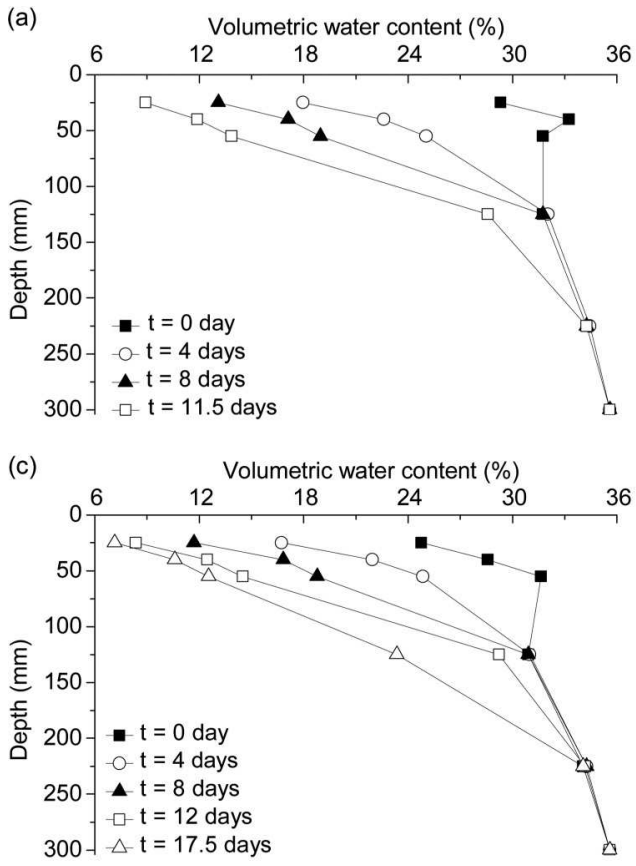
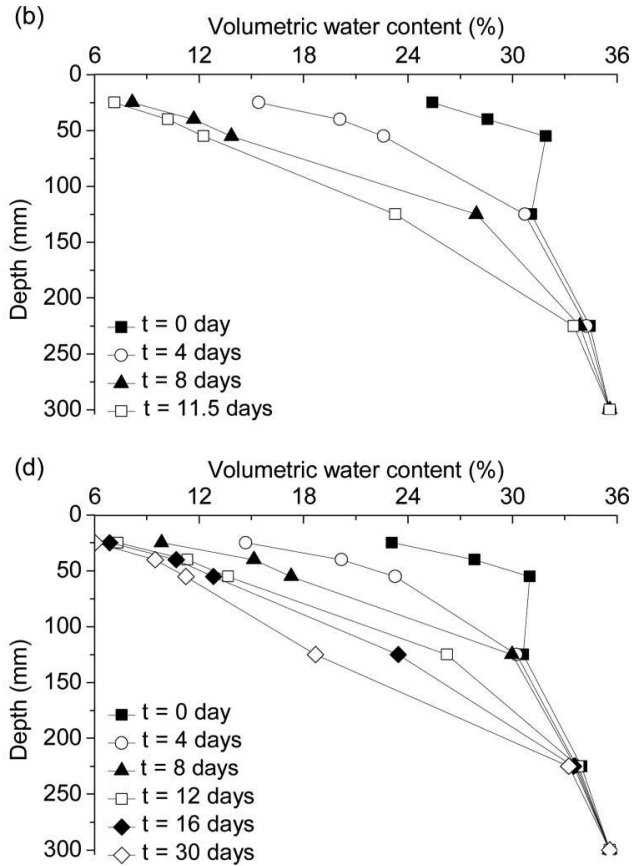

Fig. 14. Evolutions of matric suction at different positions: (a) test $1,(b)$ test $2,(c)$ test 3 , and $(d)$ test 4.
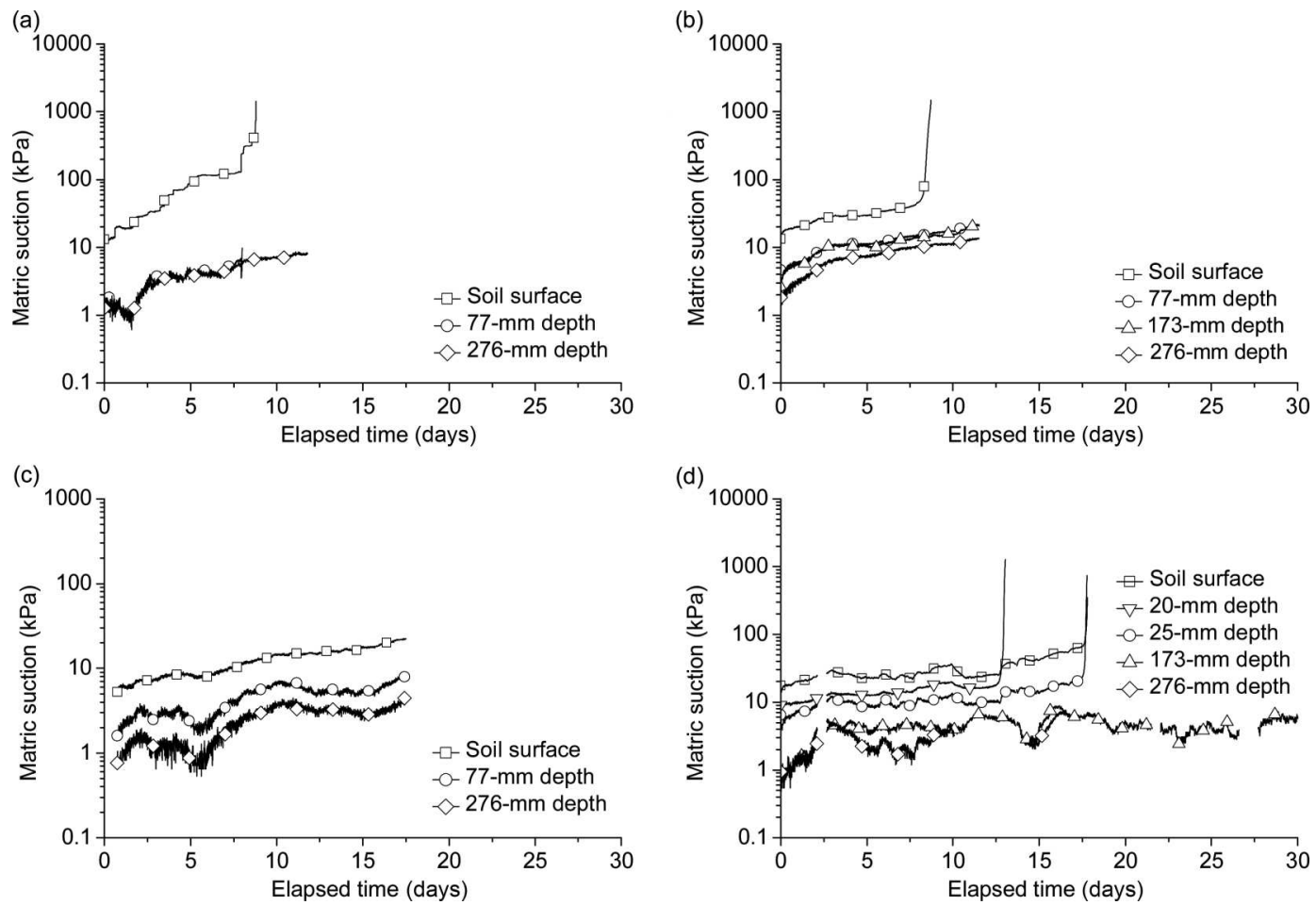

the measurement many times, thus the data are lost for the first 1.2 days at $173 \mathrm{~mm}$ depth and no data were recorded after 16.5 days at $276 \mathrm{~mm}$ depth.

The profiles of soil suction are shown in Fig. 15. For all the tests, a clear decrease over depth can be identified, with the largest gradient in the surface zone. For test 1 , the gradient from the soil surface to $77 \mathrm{~mm}$ depth varies from $0.2 \mathrm{kPa} / \mathrm{mm}$ at the beginning to $1.5 \mathrm{kPa} / \mathrm{mm}$ at $t=6$ days. For test 2 , the gradient from the soil surface to $7 \mathrm{~mm}$ depth increases from $0.2 \mathrm{kPa} / \mathrm{mm}$ at the beginning to $0.5 \mathrm{kPa} / \mathrm{mm}$ at $t=8$ days. The gradient from the soil surface

to $77 \mathrm{~mm}$ depth increases from $0.05 \mathrm{kPa} / \mathrm{mm}$ at the beginning to $0.2 \mathrm{kPa} / \mathrm{mm}$ at $t=17.5$ days in test 3 . For test 4 , the gradient from the soil surface to $25 \mathrm{~mm}$ depth increases from $0.7 \mathrm{kPa} / \mathrm{mm}$ at the beginning to $2.4 \mathrm{kPa} / \mathrm{mm}$ at $t=16$ days. On the other hand, the matric suction distribution over depth at the initiation of evaporation can be identified: for test 1 , the suctions decrease over depth and their values at the soil surface (5 $\mathrm{mm}$ depth), $77 \mathrm{~mm}$ depth, and $276 \mathrm{~mm}$ depth are 13,1.7, and $1 \mathrm{kPa}$, respectively. For test 2 , the suction values at the soil surface (10 mm depth), 77, 173, and $276 \mathrm{~mm}$ depths are 13.5, 4.6, 2.6, and $1.8 \mathrm{kPa}$, respectively. For test 
Fig. 15. Profiles of matric suction at different times: (a) test $1,(b)$ test $2,(c)$ test 3 , and $(d)$ test 4.
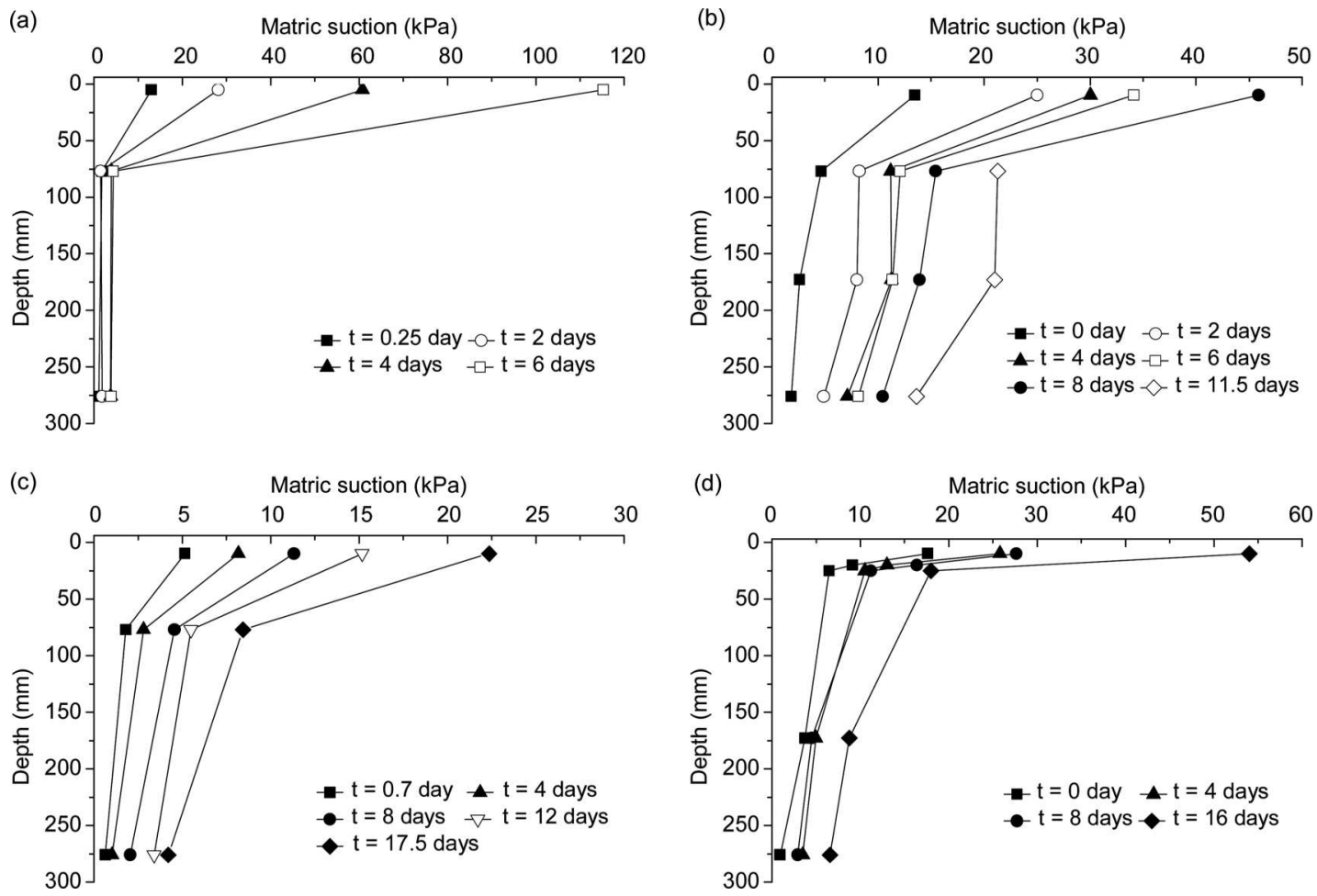

Fig. 16. Soil water retention curve obtained from the four evaporation tests.

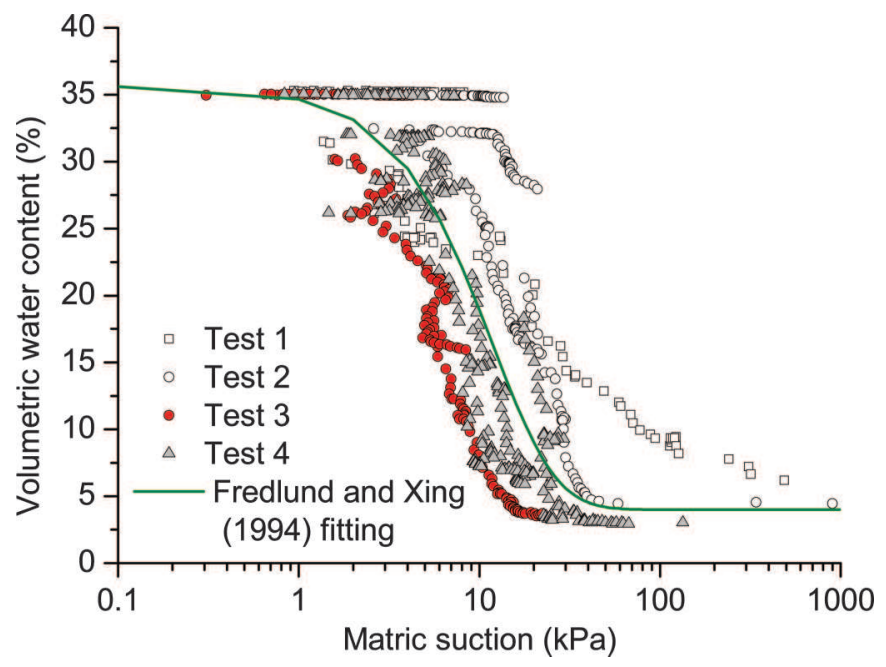

Fig. 17. Unsaturated hydraulic conductivity versus matric suction, determined by the simultaneous profile method.

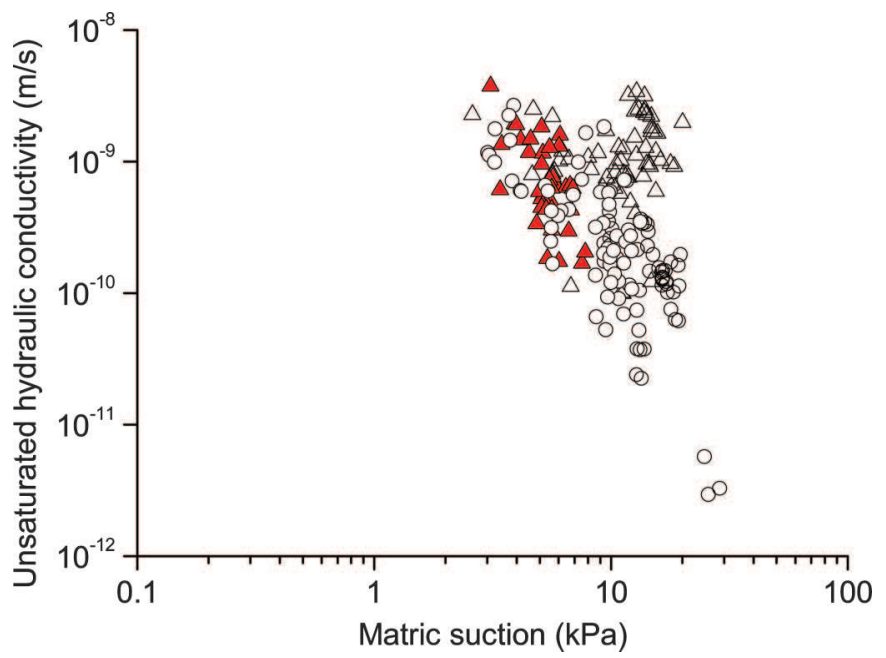

3 , the values at the soil surface (10 $\mathrm{mm}$ depth), 77 , and $276 \mathrm{~mm}$ depths are $5.2,1.8$, and $0.6 \mathrm{kPa}$, respectively. For test 4 , the values at the soil surface (10 mm depth), 20, 25, 173, and $276 \mathrm{~mm}$ depths are 17.6, 9.1, 6.5, 3.8, and $0.9 \mathrm{kPa}$, respectively.

The increasing suction in the soil suggests a gradual water loss during evaporation (see Fig. 14). The decrease of suction over depth corresponds to the increase of volumetric water content the surface soil loses water quickly during evaporation resulting in a sharp increase in suction (see Figs. 14 and 15). The increase of suction gradient in the surface zone during evaporation (see Fig. 15) confirms that water loss at the soil surface is quicker than in deeper zones. Note that the measurement of soil surface suction is essential in theoretical analysis of evaporation (Wilson et al. 1997; Aydin et al. 2005). The measurements done in this

study provide useful information in this regard, but it is worth noting that they were done slightly below the soil surface, and in addition the suction values were limited to $1.5 \mathrm{MPa}$.

\section{Soil water retention curve and unsaturated hydraulic conductivity}

Figure 16 presents the soil-water retention curve of Fontainebleau sand obtained from the four evaporation tests with simultaneous measurements of suction and volumetric water content at various depths during the drying process. In the determination, for each level of soil suction measurement (see Fig. 14), the corresponding volumetric water content was determined based on the volumetric water content profile (see Fig. 13). Figure 16 also shows 
Fig. 18. Evolutions of actual evaporation rate: $(a)$ test $1,(b)$ test $2,(c)$ test 3 , and $(d)$ test 4.
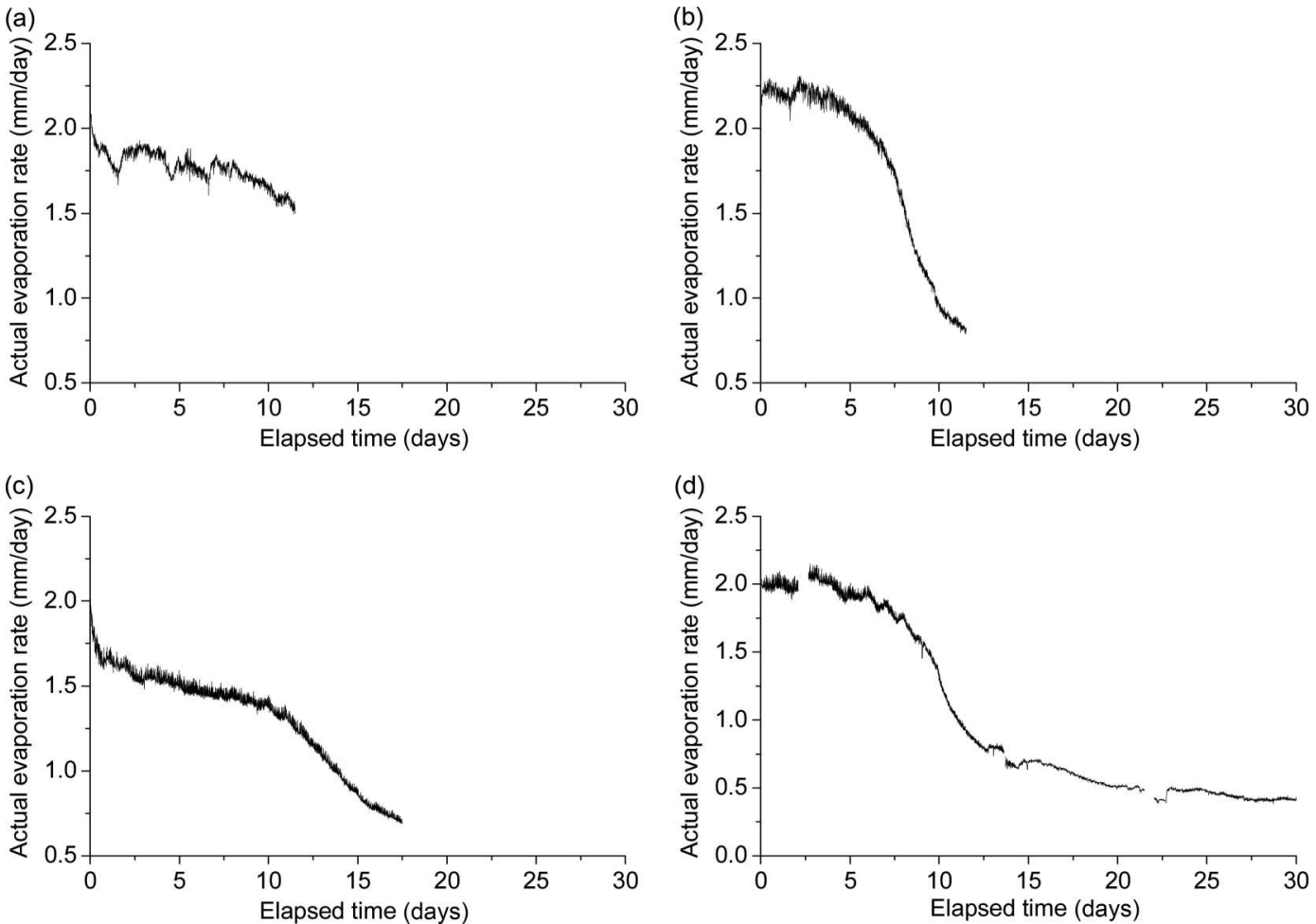

a best-fit of the water retention curve obtained using eq. (6) (Fredlund and Xing 1994)

$$
\theta_{\mathrm{w}}=\theta_{\mathrm{r}}+\frac{\theta_{\mathrm{s}}-\theta_{\mathrm{r}}}{\left\{\ln \left[e+(\psi / \mathrm{a})^{n}\right]\right\}^{m}}
$$

where $\theta_{\mathrm{w}}$ is the volumetric water content (\%); $\theta_{\mathrm{r}}$ is the residual volumetric water content $\left(\theta_{\mathrm{r}}=4 \%\right) ; \theta_{\mathrm{s}}$ is the volumetric water content in the saturated state $\left(\theta_{\mathrm{s}}=35.6 \%\right) ; e$ is the natural logarithm base ( $e=2.71828) ; \psi$ is the matric suction $(\mathrm{kPa}) ; a, n$, and $m$ are fitting parameters $(a=40, n=1.4$, and $m=15)$.

Figure 17 shows the unsaturated hydraulic conductivity of Fontainebleau sand determined by the instantaneous profile method based on the profiles of volumetric water content (Fig. 13) and the profiles of suction (Fig. 15). For more details about the instantaneous profile method, refer to the work of Cui et al. (2008b) and Wang et al. (2013). A large data scatter is observed. However, on the whole, the unsaturated hydraulic conductivity is found to decrease with the increase of matric suction. Note that different symbols in Fig. 17 represents the data obtained from different evaporation tests.

\section{Actual evaporation rate}

Based on the air temperature and relative humidity at inlet and outlet as well as the air flow rate, the actual evaporation rate can be calculated using eq. (1). The results are shown in Fig. 18 for all four tests. In general, the evaporation rate under low heating tube temperatures (tests 1 and 3) is lower than under high heating tube temperatures (tests 2 and 4). On the other hand, the evaporation rate at high air flow rate (tests 1 and 2 ) is higher than at low air flow rate (tests 3 and 4). In addition, for tests 2,3 , and 4, three stages can be identified: (i) nearly constant or slightly decreasing evaporation; (ii) a sharp decline; and (iii) stabilized or very slightly decreasing evaporation. Note that only one stage exists for test 1. Comparison between the variations of actual evaporation rate and those of relative humidity (Fig. 10) shows that they are com-

patible: an initial-decrease stage for relative humidity corresponds to a high evaporation rate; a quick-decline second stage for relative humidity corresponds to an evaporation rate reduction; a final stabilization stage with a very low decrease rate for relative humidity corresponds to a low-rate evaporation.

For test 1, the initial water content was higher than for the other three tests, and therefore the constant evaporation stage lasted longer. The effect of air flow rate on evaporation can be also identified: at the constant evaporation stage, the $172 \mathrm{~L} / \mathrm{min}$ air flow rate in test 2 resulted in a nearly $2.2 \mathrm{~mm}$ /day evaporation rate while the $130 \mathrm{~L} / \mathrm{min}$ air flow rate in test 4 led to an evaporation rate of $2 \mathrm{~mm}$ /day. The effect of air temperature appears more significant than the effect of air flow rate, especially during the constantevaporation stage. For instance, at a similar air flow rate (i.e., $185 \mathrm{~L} / \mathrm{min}$ in test 1 and $172 \mathrm{~L} / \mathrm{min}$ in test 2) but different air temperatures (i.e., 16 to $20.5{ }^{\circ} \mathrm{C}$ in test 1 and 24 to $29^{\circ} \mathrm{C}$ in test 2), the evaporation rate ranges from 1.5 to $2.1 \mathrm{~mm}$ /day in test 1 whereas it ranges from 2.0 to $2.3 \mathrm{~mm}$ /day in test 2 . Similar observations can be made from tests 3 and 4: the evaporation rate in test 3 has an average value of $1.7 \mathrm{~mm} /$ day while this value is $2 \mathrm{~mm} /$ day in test 4 .

\section{Conclusions}

Four soil water evaporation tests were carried out on Fontainebleau sand with a stable water table in a large-scale environmental chamber, with varying air temperature, air flow rate, and test duration. Both air parameters (air flow rate, temperature, and relative humidity) and soil parameters (temperature, water content, and suction) were monitored. The following conclusions can be drawn based on the results obtained.

1. The air temperature inside the chamber is affected by both the heating tube temperature and air flow rate. The air temperature in the chamber is nearly constant when the temperature in the heating tube is low, but increases when the temperature in the heating tube is high. Furthermore, the air temperature is also affected by the soil water evaporation process. 
2. Soil temperature is strongly affected by the air conditions. When the temperature in the heating tube is high, the soil temperature is increased and the heat energy for evaporation is solely from the hot air. By contrast, when the air temperature is low, the energy for evaporation comes from both air and soil. The evaporation process also influences the soil temperature: when the evaporation rate is low, the energy consumed by evaporation decreases, thus soil temperature increases by heat from hot air.

3. Relative humidity in the chamber decreases during the evaporation progress. The relative humidity in the chamber is lower at higher heating tube temperatures. The large increase at the outlet of the chamber represents water evaporation from the soil. In other words, evolution of the relative humidity in the chamber is an indicator of evaporation progress.

4. Volumetric water content in the near-surface zone is strongly affected by the evaporation process and exhibits a linear relationship with depth. The change of water content in the surface zone is related to the evolution of soil resistance to evaporation.

5. Soil suction decreases over depth and increases over time. This is consistent with the volumetric water content changes.

6. Evaporation rate is strongly affected by the air conditions especially at the initial constant-evaporation rate stage. At higher heating tube temperatures, the evaporation rate is higher. At a higher air flow, the evaporation rate was also found to be higher.

The test data obtained allowed the mechanism of water evaporation from bare sand to be revealed. They can be also used for the validation of numerical models dealing with water transfer under the effects of both soil temperature and soil suction. Most importantly, these data can be used to verify existing models for soil water evaporation or to develop new ones. From a practical point of view, these kinds of models are helpful in determining the soil surface conditions (water vapor flux, suction, temperature). When these conditions are known, common numerical models for unsaturated soils can be used to predict changes in soil temperature, soil suction, soil water content, etc. In other words, the models for soil water evaporation are essential when dealing with the interaction between the atmosphere and soils.

\section{Acknowledgements}

The authors are grateful for the financial support from the China Scholarship Council (CSC) and Ecole des Ponts ParisTech.

\section{References}

Aluwihare, S., and Watanabe, K. 2003. Measurement of evaporation on bare soil and estimating surface resistance. Journal of Environmental Engineering, 129(12): 1157-1168. doi:10.1061/(ASCE)0733-9372(2003)129:12(1157).

Aydin, M., Yang, S.L., Kurt, N., and Yano, T. 2005. Test of a simple model for estimating evaporation from bare soils in different environments. Ecological Modelling, 182(1): 91-105. doi:10.1016/j.ecolmodel.2004.07.013.

Blight, G.E. 1997. Interactions between the atmosphere and the Earth. Géotechnique, 47(4): 715-767. doi:10.1680/geot.1997.47.4.713.

Blight, G. 2009. Solar heating of the soil and evaporation from a soil surface. Géotechnique, 59(4): 355-363. doi:10.1680/geot.2009.59.4.355.

Brutsaert, W. 1988. Evaporation into the atmosphere: theory, history, and applications. D. Reidel Publishing Company, Dordrecht, the Netherlands.

Corti, T., Muccione, V., Köllner-Heck, P., Bresch, D., and Seneviratne, S.I. 2009. Simulating past droughts and associated building damages in France. Hydrology and Earth System Sciences, 13(9): 1739-1747. doi:10.5194/hess-13-17392009.

Corti, T., Wüest, M., Bresch, D., and Seneviratne, S.I. 2011. Drought-induced building damages from simulations at regional scale. Natural Hazards and Earth System Sciences, 11(12): 3335-3342. doi:10.5194/nhess-11-3335-2011.

Cui, Y.-J., and Zornberg, J.G. 2008. Water balance and evapotranspiration monitoring in geotechnical and geoenvironmental engineering. Geotechnical and Geological Engineering, 26(6): 783-798. doi:10.1007/s10706-008-9198-z.

Cui, Y.-J, Lu, Y.F., Delage, P., and Riffard, M. 2005. Field simulation of in situ water content and temperature changes due to ground-atmospheric interactions. Géotechnique, 55(7): 557-567. doi:10.1680/geot.2005.55.7.557.

Cui, Y.-J., Tang, A.-M., Mantho, A.T., and De Laure, E. 2008a. Monitoring field soil suction using a miniature tensiometer. Geotechnical Testing Journal, 31(1): 95-100. doi:10.1520/GTJ100769.

Cui, Y.-J., Tang, A.-M., Loiseau, C., and Delage, P. 2008b. Determining the unsaturated hydraulic conductivity of a compacted sand-bentonite mixture under constant-volume and free-swell conditions. Physics and Chemistry of the Earth, Parts A/B/C, 33: S462-S471. doi:10.1016/j.pce.2008.10.017.

Cui, Y.-J., Gao, Y.B., and Ferber, V. 2010. Simulating the water content and temperature changes in an experimental embankment using meteorological data. Engineering Geology, 114: 456-471. doi:10.1016/j.enggeo.2010.06.006.

Cui, Y.-J., Ta, A.N., Hemmati, S., Tang, A.M., and Gatmiri, B. 2013. Experimental and numerical investigation of soil-atmosphere interaction. Engineering Geology, 165: 20-28. doi:10.1016/j.enggeo.2012.03.018.

Delfosse-Ribay, E., Djeran-Maigre, I., Cabrillac, R., and Gouvenot, D. 2004. Shear modulus and damping ratio of grouted sand. Soil Dynamics and Earthquake Engineering, 24(6): 461-471. doi:10.1016/j.soildyn.2004.02.004.

Fredlund, D.G., and Xing, A. 1994. Equations for the soil-water characteristic curve. Canadian Geotechnical Journal, 31(4): 521-532. doi:10.1139/t94-061.

Kondo, J., Saigusa, N., and Sato, T. 1992. A model and experimental study of evaporation from bare-soil surfaces. Journal of Applied Meteorology, 31(3): 304-312. doi:10.1175/1520-0450(1992)031<0304:AMAESO>2.0.CO;2.

Mohamed, A.A., Sasaki, T., and Watanabe, K. 2000. Solute transport through unsaturated soil due to evaporation. Journal of Environmental Engineering, 126(9): 842-848. doi:10.1061/(ASCE)0733-9372(2000)126:9(842).

Muñoz-Castelblanco, J.A., Pereira, J.M., Delage, P., and Cui, Y.J. 2012. The water retention properties of a natural unsaturated loess from northern France. Géotechnique, 62(2): 95-106. doi:10.1680/geot.9.P.084.

Qiu, G.Y., Yano, T., and Momii, K. 1998. An improved methodology to measure evaporation from bare soil based on comparison of surface temperature with a dry soil surface. Journal of Hydrology, 210(1-4): 93-105. doi:10.1016/S00221694(98)00174-7.

Shimojimaa, E., Yoshioka, R., and Tamagawa, I. 1996. Salinization owing to evaporation from bare-soil surfaces and its influences on the evaporation. Journal of Hydrology, 178(1-4): 109-136. doi:10.1016/0022-1694(95)02826-9.

Song, W.K., Cui, Y.J., Tang, A.M., and Ding, W.Q. 2013. Development of a largescale environmental chamber for investigating soil water evaporation. Geotechnical Testing Journal, 36(6): 847-857. doi:10.1520/GTJ20120142.

Tang, A.-M., Cui, Y.-J., Qian, L.-X., Delage, P., and Ye, W.-M. 2010. Calibration of the osmotic technique of controlling suction with respect to temperature using a miniature tensiometer. Canadian Geotechnical Journal, 47(3): 359365. doi:10.1139/T09-097.

van de Griend, A.A., and Owe, M. 1994. Bare soil surface resistance to evaporation by vapor diffusion under semiarid conditions. Water Resources Research, 30(2): 181-188. doi:10.1029/93WR02747.

Wang, Q., Cui, Y.-J., Tang, A.M., Barnichon, J.-D., Saba, S., and Ye, W.-M. 2013. Hydraulic conductivity and microstructure changes of compacted bentonite/ sand mixture during hydration. Engineering Geology, 164: 67-76. doi:10.1016/ j.enggeo.2013.06.013.

Wang, W.Z. 2006. Wind tunnel experiments on bare soil evaporation. M.Sc. thesis, Department of Civil Engineering, National Central University, Taiwan.

Wilson, G.W. 1990. Soil evaporative fluxes for geotechnical engineering problems. PhD. thesis, Department of Civil Engineering, University of Saskatchewan, Saskatoon, Sask.

Wilson, G.W., Fredlund, D.G., and Barbour, S.L. 1994. Coupled soil-atmosphere modelling for soil evaporation. Canadian Geotechnical Journal, 31(2): 151161. doi:10.1139/t94-021.

Wilson, G.W., Fredlund, D.G., and Barbour, S.L. 1997. The effect of soil suction on evaporative fluxes from soil surfaces. Canadian Geotechnical Journal, 34(1): 145-155. doi:10.1139/t96-078.

Wythers, K.R., Lauenroth, W.K., and Paruelo, J.M. 1999. Bare-soil evaporation under semiarid field conditions. Soil Science Society of America Journal, 63(5): 1341-1349. doi:10.2136/sssaj1999.6351341x.

Xue, Z., and Akae, T. 2012. Maximum surface temperature model to evaluate evaporation from a saline soil in arid area. Paddy and Water Environment, 10(2): 153-159. doi:10.1007/s10333-011-0286-y.

Yamanaka, T., Takeda, A., and Sugita, F. 1997. A modified surface-resistance approach for representing bare-soil evaporation: Wind tunnel experiments under various atmospheric conditions. Water Resources Research, 33(9): 2117-2128. doi:10.1029/97WR01639.

Yanful, E.K., and Choo, L.-P. 1997. Measurement of evaporative fluxes from candidate cover soils. Canadian Geotechnical Journal, 34(3): 447-459. doi:10.1139/ t97-002.

Yanful, E.K., Mousavi, S.M., and Yang, M. 2003. Modeling and measurement of evaporation in moisture-retaining soil covers. Advances in Environmental Research, 7(4): 783-801. doi:10.1016/S1093-0191(02)00053-9.

Yang, M., and Yanful, E.K. 2002. Water balance during evaporation and drainage in cover soils under different water table conditions. Advances in Environmental Research, 6(4): 505-521. doi:10.1016/S1093-0191(01)00077-6.

Zarei, G., Homaee, M., and Liaghat, A. 2009. Modeling transient evaporation from descending shallow groundwater table based on Brooks-Corey retention function. Water Resources Management, 23(14): 2867-2876. doi:10.1007| s11269-009-9413-6. 